\title{
HISTORICAL RELATIONSHIP OF MINING, SILICOSIS, AND ROCK REMOVAL
}

\author{
BY \\ TREVE HOLMAN \\ Camborne, Cornwall \\ (RECEIVED FOR PUbLICATION, AUgUST 7, 1946)
}

\section{Introduction}

The interwoven relationship of mining, silicosis, and rock removal has existed for thousands of years, from long before historical record. Mining, of all collective enterprise, is the most ancient. Man's ability to find, form, and use flint tools was an early step in his development. Some 10,000 or more years ago underground work began with the sinking of shafts and driving of tunnels for flints for use as knives, axes, arrow-heads, and other implements. In many European countries evidences of such neolithic work have been discovered. Mining in antiquity carried its hazards as it does to-day, but in a far more aggravated form. Violent death was an ever-present danger. Improvement has occurred over the centuries, but due to the nature and conditions of his employment the miner has always been susceptible to occupational disease.

The technique of rock removal was from the earliest days an important concomitant of mining for metals. Its development was the principal factor in the advancement of mining itself.

Dust created by rock removal is by no means confined to rock drilling. Blasting, shovelling, transporting, crushing, winding to surface, are operations during which dust may be, and generally is, released into the atmosphere. These factors are not examined in this review, which is confined to the drilling of holes in rock. An attempt is made to outline the progress in rock drilling along each of the three drilling operations, drifting, underhand stoping, and overhand stoping, and to show how the gravity of resultant occupational disease increased with the intensity of operations until a belated realization of the problem called a halt. Great improvements have been made, but the effect has been uneven in this country. Unless safeguards for the protection of miners' health are universally adopted, labour may seek surface employment, or the recompense demanded may injure dependant industries. The safeguards are well known and well tried. No mine or quarry should operate without them.

\section{Period I.-Prehistoric Surface Excavations and Shallow Holes}

Even in the earliest times mining in its most elementary form appears to have caused diseases. It has been suggested by Rosen that ancient miners suffered from silicosis, as signs of pneumonoconiosis have been observed in prehistoric man. In Egyptian mummies anthracosis and pleural adhesion have been found. Flint-knapping, the oldest of industries, remains to this day a source of mortality from phthisis through flint dust. It is, therefore, a reasonable assumption that in period $\mathrm{I}$, as the only tools available, other than horn, were of flint, the working of this material caused a serious liability to lung disease.

As regards actual mining, the methods of excavation were entirely by hand and, whilst slow and extremely laborious, were relatively free from dust. The workings being shallow, natural ventilation no doubt sufficed to keep them supplied with breathable air. It is probable that the worst dangers which faced the prehistoric miner were from falls of ground and inrush of water.

Period II.-Deeper Mining by Manual Labour

This long period reaches from the dawn of recorded history down through mediaeval times to the earliest days of the industrial revolution. The work remained slow and laborious as mechanization had not begun, but there was a gradual improvement in the tools used. Flint was superseded by bronze of a steadily improving quality, which in its turn gave place to iron, also subject to steady improvement as timte went by. When metal mining began is unknown, but there is little doubt that bronze tools were in use 6,000 years ago. Large-scale mining operations were carried on in Egypt with the aid of metal tools. The removal of hard rock was 
achieved by building a fire against the face and then by throwing water on the heated rock. The first specific reference to 'fire setting' in mining is by Agatharchides in the second century B.c. (see Hoover, 1912). The same method was customarily used through Greek, Roman, and mediaeval times on into the seventeenth century, when it was

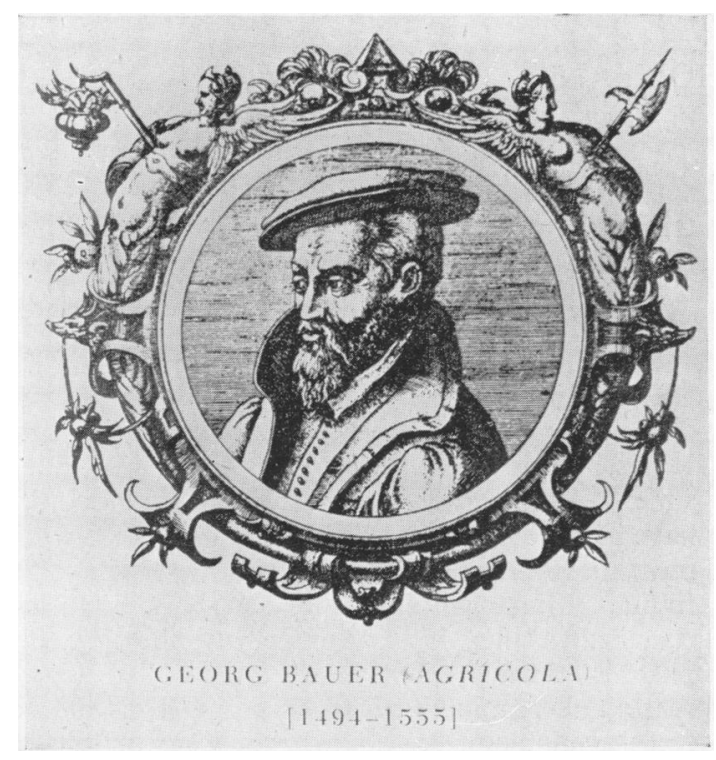

Plate I.

gradually displaced by blasting with gunpowder. Until the invention of safety fuse by Bickford in 1831 the blasting powder was ignited from straws filled with fine-grained powder, and frequent accidents occurred. Although the working conditions as mentioned by the ancient writers were of appalling description, yet it is possible that defective ventilation, falls of ground, and hook-worm were the chief causes of casualties. The production of dust through mechanical drilling operations had not yet begun, but some dust was caused by the work, and Pliny mentions the use of bladder-skins as primitive respirators to cover the mouths of miners.

After the fall of Rome the records of mining ceased until the great work of Agricola was published in 1556 in Latin, under the title of ' De re Metallica.' It was translated by Herbert Hoover the American Mining Engineer in 1912, and was published in a well-produced limited edition. It is illustrated by the original woodcuts, which are of the greatest technical interest. Agricola (Plate I) made a thorough investigation into mining practices in Germany, which was then the leading country in the industry. Being a Doctor of Medicine, he included in his observations an account of the diseases and accidents prevalent amongst the miners.

The breaking of rock followed the earlier methods of hewing with metal tools, except for the harder rocks, where fire was used. In the drier mines considerable trouble from dust was experienced. Agricola says, "If the dust has corrosive quality it eats away the lung and implants consumption in the body.' He makes the statement that, in the mines of the Carpathian Mountains, women are found who have married seven husbands in turn, all of whom died from consumption. With the introduction of gunpowder for blasting at Schemnitz by Casper Windt in 1627 the drilling of holes began. A form of machine drill was tried in 1636, but it may be taken that during the period under review. practically the whole of the work was carried out by hand.

There is no doubt that one of the causes of the grave mortality amongst the miners was their low social status and entire lack of sympathy and care from the rest of the population. In the earlier days of this period only slaves were used underground, who were driven at work until they died. Even in the latter years of the period, miners were regarded as people apart and their laws and conditions of life were separate from those of the rest of the community. For instance, in Cornwall the tinners were governed by the Stannary Courts (Lewis). In spite of a somewhat contemptuous valuation there is no question that great skill was essential and was present. A man's life was in his own hands, and carelessness and ignorance was repaid by injury or death.

\section{Period III}

Mining.-This period carries the story from 1700 to the middle of the Victorian era. During this time the mines were increasing rapidly in depth, due to the great improvement in the pumping of water to keep the mines dry. Steam had been set to work by Newcomen in 1712, and this great advance had been continued by a succession of engineersSmeaton, Watt, Murdock, Hornblower, Trevithick, Woolf. By the close of this period mines could be worked to a depth of 1,800 or more feet.

Ventilation was becoming more difficult, as rock temperatures were rising steadily with the increase in depth. In the St. Day district in Cornwall it is recorded that at Poldice Mine the water from the 184 fathom level (1104 ft.) registered $100^{\circ} \mathrm{F}$. Air in the deeper levels of the mines was between $80^{\circ}$ and $100^{\circ} \mathrm{F}$. (Jenkin). Truscott states: ' The rate of the increase of temperature with depth, known as the geothermal gradient, varies from region to region, 


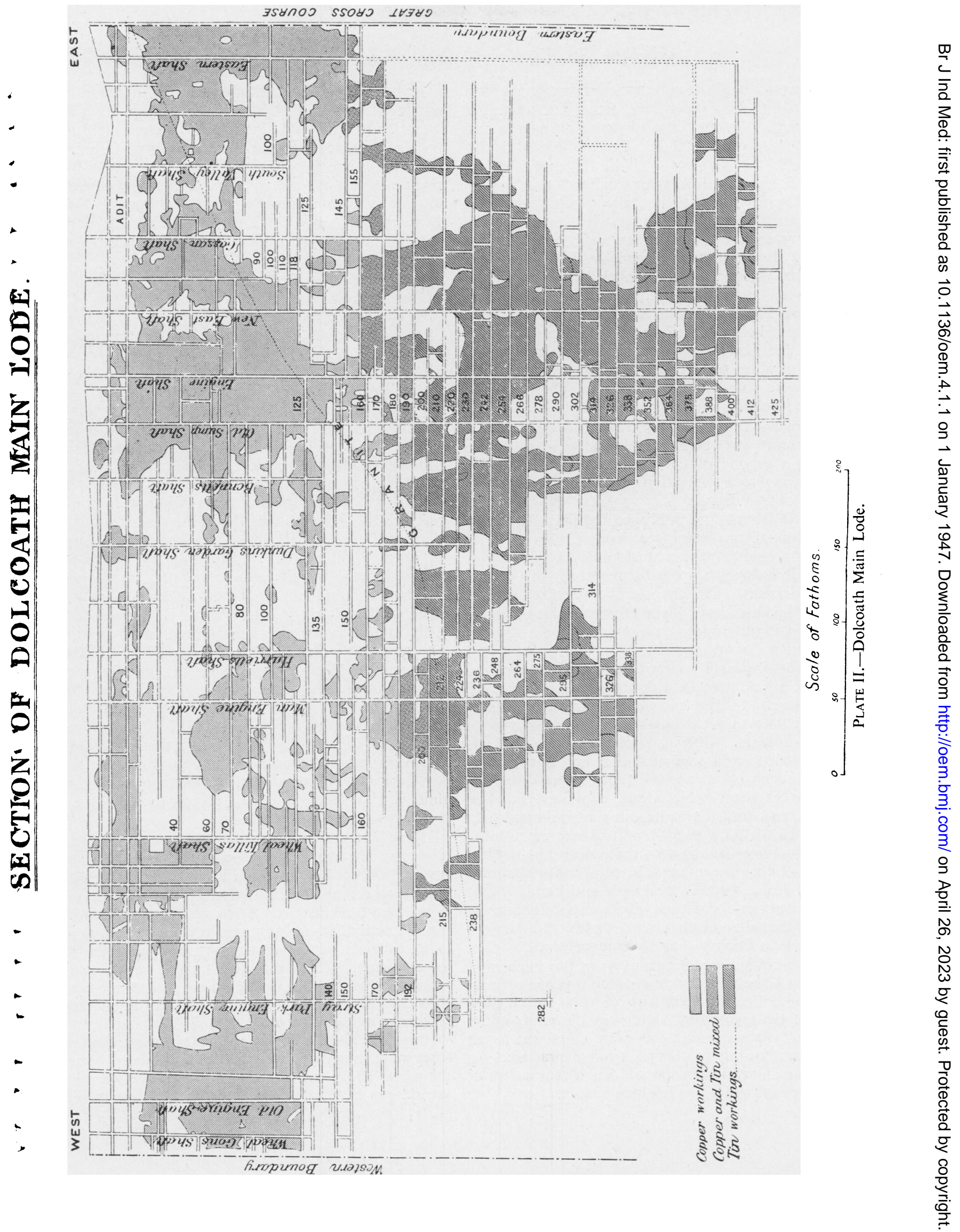


it is lowest where the country has been long a land surface and long been free from intrusion and movement. On the Witwatersrand there is a rise of $1^{\circ} \mathrm{F}$. for every $212 \mathrm{ft}$. On the Indian Kolar Goldfields the gradient is $1^{\circ} \mathrm{F}$. for every $150 \mathrm{ft}$. In the British and European Coalfields the figure is $1^{\circ} \mathrm{F}$. for $65 \mathrm{ft}$.' At the time when these great temperatures were being met with, many of the mines were without any proper ' dries' or changinghouses. Long draughty sheds without doors or windows, where the wind whistled through on the half-naked men, were frequently the only places provided for the miners on coming up from the great heat below. As late as 1842 , the men in a great mine like Fowey Consols had no real 'dry,' no warm water to wash with, whilst in winter their shoes were sometimes frozen in the chests on the surface (Jenkin).

Silicosis. - During this period occupational disease in general was being intelligently investigated. Mining was one of the industries brought under view owing to a realization of the shortness of life of miners as a class.

In 1700 Ramazzini published the first treatise on occupational medicine (see Rosen). $\mathrm{He}$ was an eminent Italian physician of Modina. His book laid a firm foundation for the further study of occupational diseases. The chapter of immediate interest is on 'The Diseases of Metal Diggers.' He mentions that in antiquity mining was regarded as a suitable punishment for criminals. He goes on to state that this opinion was still widely held in his day and adds, 'Indeed it seems to be a doubtful case whether we ought to reckon it a good and pious office to prescribe physic to such wretches and thereby prolong a miserable life.' Nevertheless, he continued his investigations and suggested that any lung pathology in such workers might be due to deposits of the metallic elements which were contained in their bodies, and that the same thing might happen in the lungs of the workmen. In discussing prophylactic measures he suggests ventilators and respirators, and that the miners be provided with boots and gloves to protect their legs and hands. This wise suggestion for the use of gloves is still observed only in Canada and the United States. In many of the mines in Canada they are compulsory.

In the collieries in England as in the mines and collieries elsewhere, the miner's life was one of great hardship. For instance, it is said that in the early days of the eighteenth century in the gassy mines on the Tyne putrescent fish were employed as an illuminant owing to danger from explosion. An old Cornish version of the tale has it that a dish of mackerel showed up a rich lode proper.
Investigations were continued both in this country and in Germany. In 1745 Henkel (see Rosen) drew attention to a method of testing the presence of dust by placing a smooth stone or a glass plate in a dry spot whilst work was going on in the mine; he mentioned the astonishment at observing how much dust collected in this way within 6 to 8 hours. This was probably one of the earliest, if not the first, description of an attempt to measure concentration of dust in mine air.

In 1799 Thomas Beddoes said that the inhalation of dust might be conducive to the establishment of a tuberculous condition. He recommended a change of occupation. In 1832 was published an important work by a Leeds physician, Charles Thackrah. Six pages are devoted to the diseases of miners. He draws attention to injury to health from dust, and suggested a 'common watering' of the stone being worked. He recommends periodic health examinations for all workers, proper muscular exercise, frequent baths at regular intervals, with proper bath facilities and plenty of fresh air. Nearly 100 years were to pass before these recommendations received the attention they deserved.

In 1859 Schirmer pointed out that detrimental influence of bituminous coal dust on the lungs was best prevented by adequate ventilation of the pits and by 'isolating' the workers from the atmosphere filled with coal dust by which they were surrounded. This 'isolation' would be achieved most expediently by the wearing of Jeffrey's respirator. The workers should also wash frequently, take frequent warm baths, and change their clothes oftener. In mentioning these suggestions Rosen adds, ' Yet while physicians proposed various prophylactic measures they were in no position to make them effective. The very fact that the same suggestions recur in the writings of various authors, at different periods, is sufficient evidence that they exercised little or no influence on existing conditions.'

Mine inspection during this period was a complete travesty. In the evidence given before a Parliamentary Select Committee in 1865 the following was stated regarding the inspection of the collieries in one important district. There was one inspector, an old man of 70 years of age, to inspect more than 130 collieries. He had been in one pit once in seven years. This is understandable when it is realized that in 1865 Great Britain had 3,217 coal mines to be visited by 12 inspectors; or about 268 collieries to every inspector.

However bad the conditions were in the collieries, they were much worse in the Cornish mines. Barham, in 1871, wrote a report after investigating conditions in Cornwall and Devon. He compared 


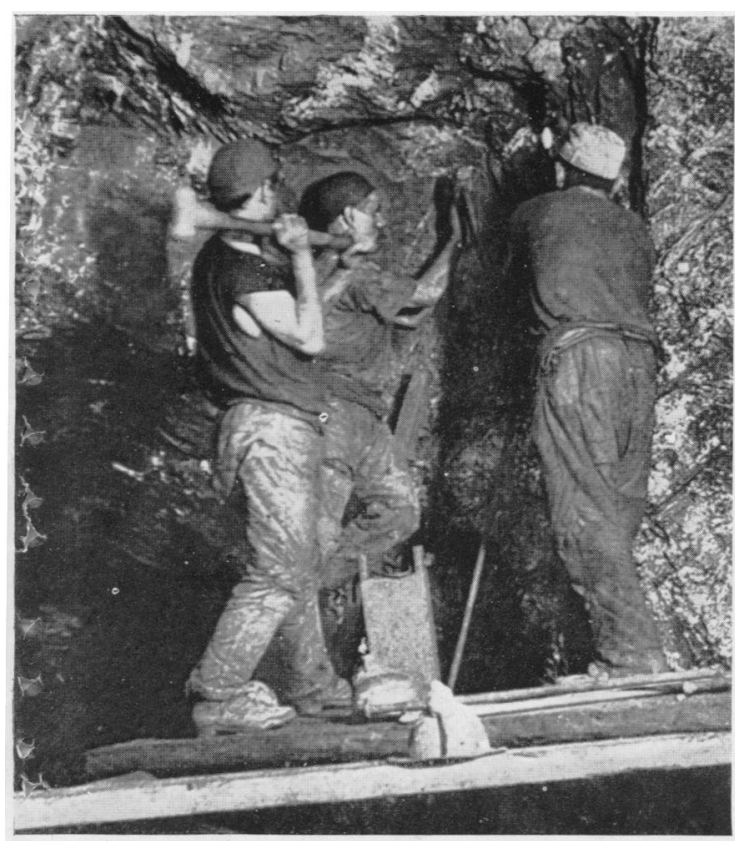

Plate III.-Hand drilling (drifting).
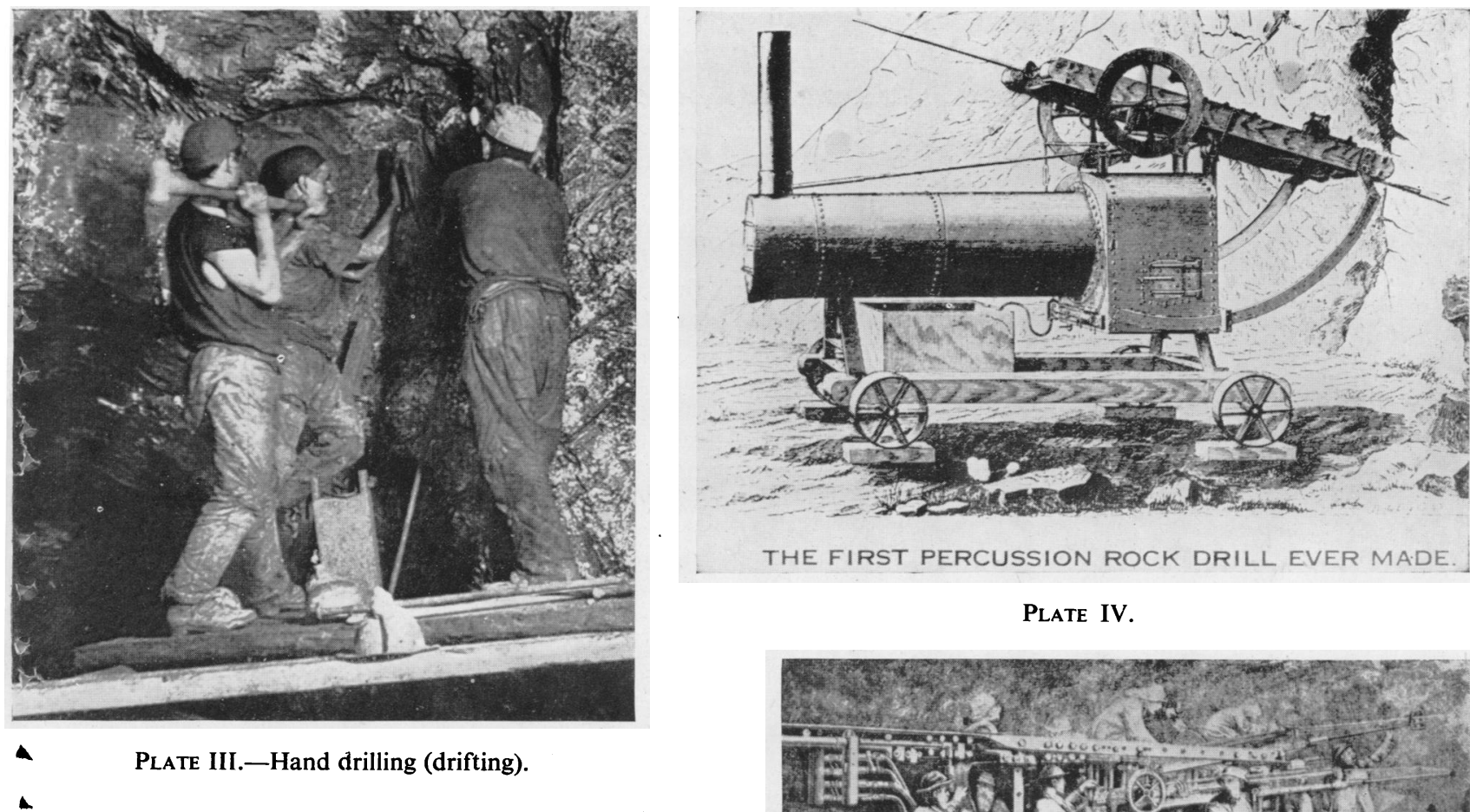

THE FIRST PERCUSSION ROCK DRILL EVER MADE.

Plate IV.

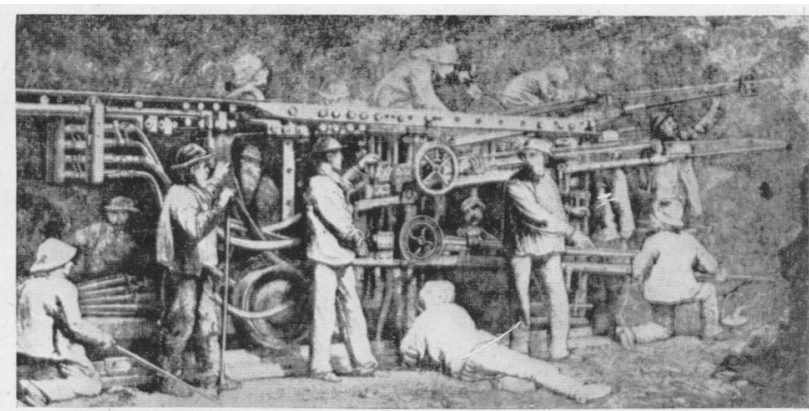

Plate V.-Mont Cenis Tunnel.

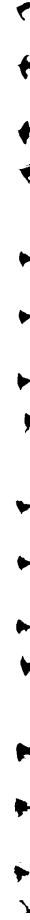

Plate VI.-Doering drill, 1867. 
the difference in mortality between miners and nonminers and stated that it was not very great until after the age of 35 ; then it increased rapidly, till from 45 to 65 there was a very pronounced excess among the mining class. He compared the mortality of the Cornish miner with that of the other great mining districts and that of all occupations in the whole of England. Out of 10,000 males who attained the age of 15 , there were registered as dying of all lung diseases :

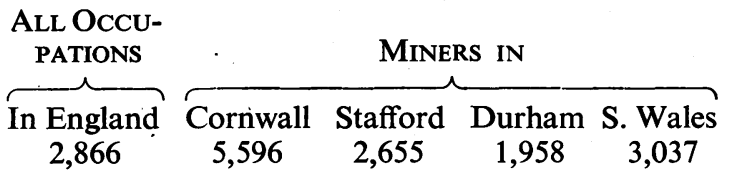

In spite of evidences which had accumulated regarding the danger of dust, the conclusions reached in 1862 by the Royal Commission appointed to study health conditions amongst metal miners stated that miners' phthisis was due to bad hygienic conditions rather than to the action of inhaled dust. This was unfortunate, as it diverted attention from the dust problem. However, in 1865 Greenhow investigated a portion of a black lung obtained from a coal miner, in which he recorded the presence of silica. He attempted to detect this by the use of polarized light. He had already used this method for the microscopic identification of silica particles in the lung of a razor-grinder. This is probably the earliest instance of the use of polarized light, and although unsuccessful, it is worth noting. The method actually used was to expose the residue to the fumes of hydrofluoric acid, which caused dissipation. Rosen states, 'within these broad outlines Greenhow's conception approaches quite closely the modern views on the subject as summed up and expressed in the generic use of the term silicosis.'

Rock Removal.-Work was most arduous under the then existing conditions, as the drilling of holes for blasting and the removal of the blasted rock was by hand (Plates III-drifting ; XIX-underhand stoping ; XXVIII-overhand stoping). Some plug and feather breakage of rock was used in which taper wedges were driven by sledge hammers into holes already drilled, thus splitting off pieces of rock. Some fire setting was still in use, and Collins records that in Königsberg an advance of from 5 to $20 \mathrm{ft}$. per month in headings was accomplished (Hoover), but blasting had become the normal method of rock removal and, as recent research has proved, was a very prolific source of dangerous dust. Blasting operations were crude and full of danger arising not only from premature explosion, but from picking out the holes which frequently misfired. Dr. Paris (Jenkin, p. 218) describes more than eighty accidents from this source which occurred in a short space in the Cornish Hundred of Penwith alone. Unlike the blasting accidents of to-day, the sufferers were more often mangled than killed outright. The numbers of men in the mining districts with faces blackened and blinded in one or both eyes, or else lacking two fingers of the right hand, used formerly to be very great.

Dynamite was introduced by Nobel in 1867. It was safer to transport, handle, use, and store than black powder; at the same time it was six times more effective. The increased shattering effect on rock no doubt greatly increased the quantity of dust liberated.

Machine drills were introduced towards the end of the period but were crude, heavy, and troublesome. The first percussive rock drill was made by Couch in Philadelphia in 1849 (Plate IV). Fowle, also of Philadelphia, followed in 1851, using the direct stroke and self-rotating principle. The first great drilling project (Plate V) which did much to concentrate the attention of civil and mechanical engineers on the problem of rock removal was the driving of the Mont Cenis tunnel in 1854 (Darlington). Compressed air was introduced, and a modified form of the Fowle drill was developed by French and Italian engineers. Later Burleigh improved the Fowle drill in the U.S.A., and used it in driving the Hoosac tunnel-another spectacular achievement. Thereafter designs came quickly. Between 1849 and 1870 sixteen different rock drills were brought out, but all were immature and a continuous source of trouble. Many of the designs were most ingenious and incorporated features such as automatic advancement of the machine as drilling proceeded, combined with automatic rotation (Plate VI). These features were far ahead of their time, and it is only in the last ten years that they have been solved in a practical and reliable form. The failure of the early drills was due less to faults in conception than to faults in execution. Owing to the immature state of metallurgical science the metals used could not withstand the work, nor had machine tools reached that standard of exact production which the designs required.

Considerable dust must have been created by these machines as little or no attempt was made to prevent it. The rate of drilling was very low and, therefore, less dust would have been created than was made by the more efficient rock drills of the next period.

\section{Period IV}

Mining.-The fourth period covers from midVictorian times to 1912 . During this time immense 

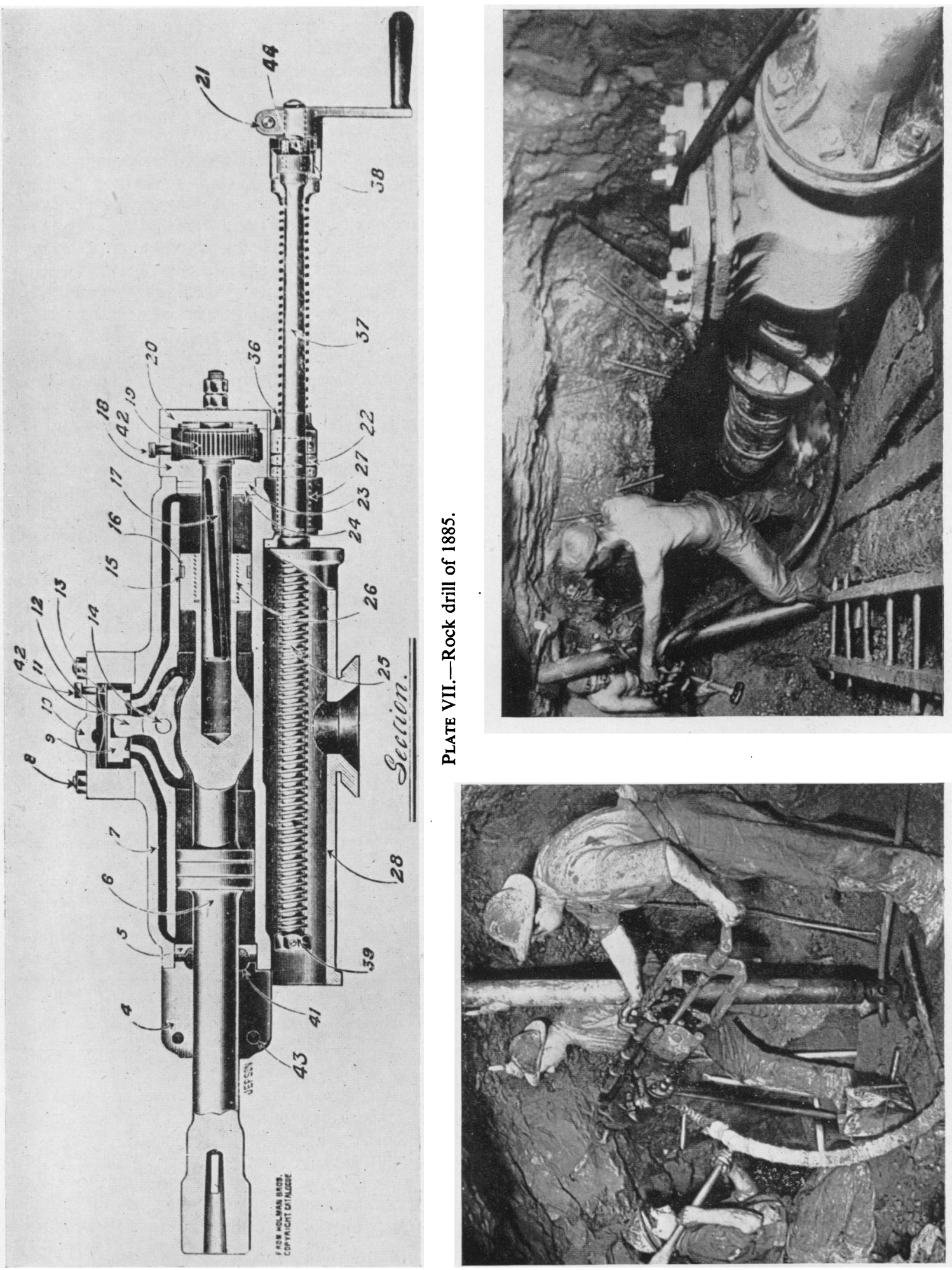


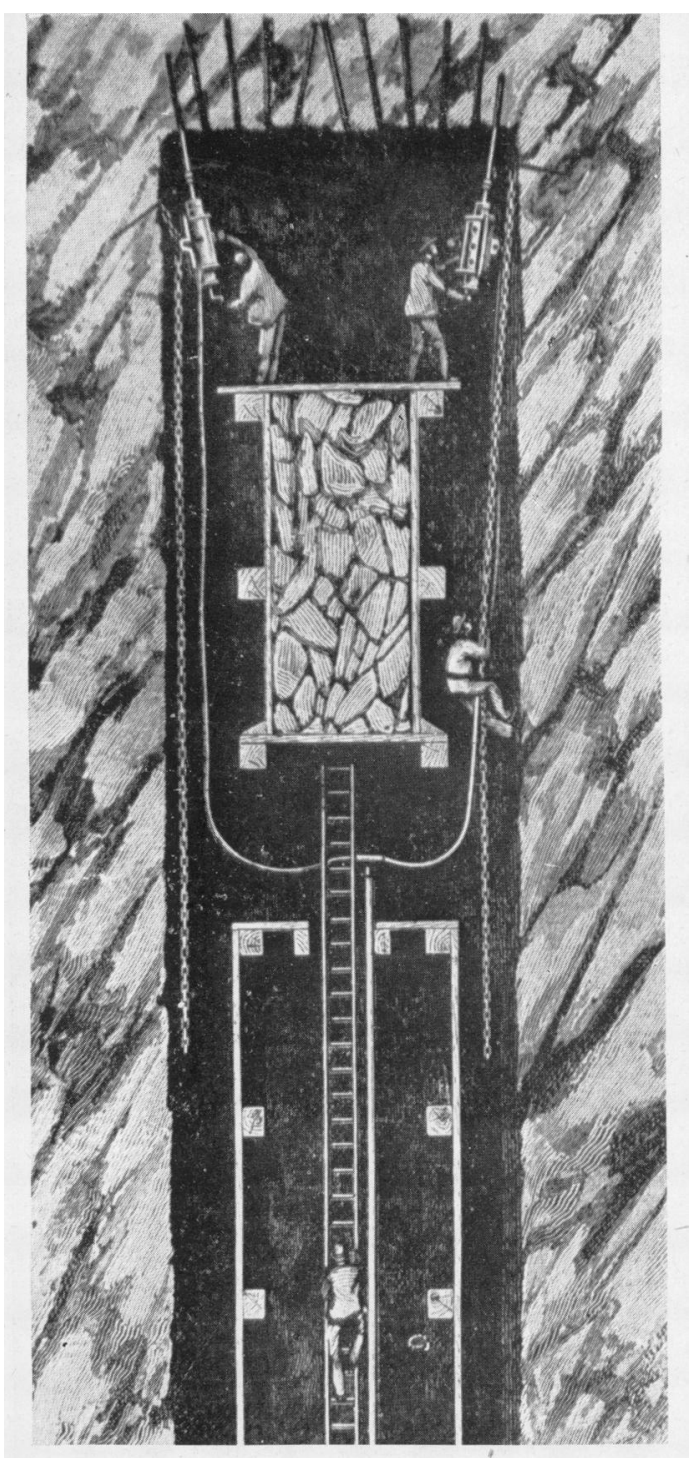

Plate X.-Early shaft raising.

mining activity took place all over the world. Gold was found in great quantities in South Africa, California, and Western Australia. Large deposits of copper were discovered in the United States, South America, Spain, and elsewhere. Rich tin mines were opened in Bolivia. Cornish miners performed a most important task in this great activity, which was in fact in many cases initiated by them. This was due to the serious slump in Cornish mining towards the end of the nineteenth century. Some of the richer mines were exhausted and the price of tin and copper fell, owing to the rich deposits discovered overseas. Also a big change had been taking place in social conditions in England, as pewter, which had consumed vast quantities of tin, passed out of fashion and earthenware was substituted for it.

Silicosis.-The continuation of these circumstances caused a vast dispersal by emigration of Cornish miners. Lord Courteney of Penwith investigated the effect on the county and states that between 1851 and 1891 170,000 Cornish miners emigrated overseas. They carried with them the virtues and also, it is feared, the vices of Cornish mining methods. The most serious of these latter was the total disregard of the danger of dust. In spite of the great scale on which some of the Cornish mines had been worked, as is shown by the section of Dolcoath Main Lode (Plate II), no attempt had ever been made to mitigate this danger, and even towards the end of the period the miner who came up to ' grass' at the end of the shift without being as white as a miller and covered from head-eyes, nose, and mouth-to foot in dust was regarded as not having done a proper shift's work by the Bal Captains. Some of the more careful men provided themselves with a sponge which they kept in their mouths. The particular mining operation which caused the most serious harm was that of the ' raising' of shafts. Plate X clearly indicates this practice. When it is realized that no method of water injection was used and that men were looking upwards with the fine siliceous dust falling on their faces, it is clear that these ' raises' were death traps of the most savage description.

Rosen cites Ogle who wrote, in 1892, that Cornish miners still suffer from an excessive rate of mortality while coal miners were more fortunately situated. The following table gives comparative figures:

\begin{tabular}{l|c|c|c}
\hline \multicolumn{1}{c|}{ Age 25-65 } & Phthisis & $\begin{array}{c}\text { Lung } \\
\text { diseases }\end{array}$ & $\begin{array}{c}\text { Phthisis } \\
\text { and lung } \\
\text { diseases }\end{array}$ \\
\hline Cornish Miners & 348 & 231 & 579 \\
Coal Miners & 64 & 102 & 166 \\
\hline
\end{tabular}

From these figures it is evident that the mortality from phthisis among Cornish miners was exceedingly great. Ogle states that it is from five to six times as high as that of fishermen, who have a low rate of mortality. Apparently health conditions amongst Cornish miners had not improved at all in the thirty years from 1862 to 1892 . From the various 
reports and tables published at the end of the nineteenth century it is clear that the period in life when the miner's occupation began to have the most serious effect was after 55 . It was then that respiratory diseases took their toll.

Medical investigation was being directed more and more to occupational disease arising from dust. Rosen quotes Eulenberg, writing in 1876, as drawing an important conclusion on this problem. This was the significance of the quartz content of various dusts. He emphatically pointed out the dangerous qualities of this mineral. Shortly before, Hirt divided dust into the categories of organic and inorganic, and again into metallic and mineral varieties. Within these various groups he differentiated between pointed or sharp-edged dusts that might injure the tissues, and dull round particles.

The importance of this difference is discounted nowadays but attention is drawn to the fact that the siliceous crystals found in the rocks of the Witwatersrand in South Africa are of needle-like form. Silicosis has been a grave scourge there for many years, and, in spite of the preventive measures taken, the disease has not been eliminated. On the other hand, in the rocks of the Kolar goldfields in South India the needle-like form of crvstal is absent. No water is used underground owing to the great humidity, and almost all drilling is done by the reciprocating type of rock drill, similar to that shown in Plate XX, p. 17. As explained on p. 10, this type of machine does not require an air blast to remove dust from the hole, but nevertheless it proved dangerous on the Witwatersrand. Silicosis has only recently assumed the dimensions of an occupational disease in the Kolar goldfield; and, therefore, despite the current solubility theory of silicosis, it is possible that Kolar dust, owing to its 'dull round' form, may not be so deeply penetrative and accumulative. It might, therefore, be less able to exert the same toxic effect as that of the Witwatersrand. 'Good housekeeping' in the way of ventilation is in force ; but it is clear that in drilling dry the miner would be very rapidly 'infected' by dust, and silicosis would have been a grave problem long since if the dust were as deleterious as on the Witwatersrand.

As this period advanced the death rate from silicosis caused people to direct attention more and more to suppression of dust in rock drilling at the source. In the early days of the period, in 1879, the use of a stream of water directed at the point which was being bored was found by Hesse and Harting to diminish the formation of dust almost completely. It was probably during the driving of the St. Gothard tunnel that the use of water was first tested, and it was the news of these experiments that caused Hesse and Harting to make their scientific investigation. As a result of their experiments they proposed the following prophylactic measures: (1) obligatory introduction of wet boring; (2) the institution of adequate ventilation; (3) the introduction of cages for the transportation of miners up and down shafts; (4) the furnishing of working clothes, including shoes for the men; (5) the institution of a dressing-room within the shaft buildingheated in winter-where the miners could change their clothes on leaving and entering the pit. It is interesting to reflect that these recommendations were published 67 years ago, and yet the vitally important recommendation No. 1, and the hardly less important No. 5, are not yet obligatory or universal in this country.

Rock Drills.-There was a remarkable advance in the mechanical developments in mining as they affect rock drilling. There is a theory that all mechanisms pass through three stages. The first stage is the inception of the idea when a crude appliance gives an indication of what is possible. In the second stage the machine becomes more reliable but also very elaborate in design and complex in construction. In the third stage an effective device results. The period under review brings us to the beginning of that final stage as applied to the rock drill. The Ingersoll and Rand drills were produced in 1870 . Ten years later the Holman went to work in the Cornish mines, to be followed shortly afterwards by the Stephens (Climax). The Ingersoll later amalgamated with the Rand; and that firm, together with the Holman and Climax Companies, remain amongst the principal rock drill manufacturers of the world to-day. Many others appeared about this time but have long since disappeared.

Machine mining spread with great rapidity, as the speed of drilling was three to four times higher than by hand and about the same cost per foot. It relieved men of the strenuous labour of beating a 'borer' steel by hand-swung sledge hammers (Plates III, XIX, and XXVIII). Compressed air from the rock drills improved the ventilation, and the expansion of the air helped to reduce the ambient temperature. Men could work in places which were quite impossible before, but this was probably a double-edged advantage, from a miner's health standpoint. The types of rock drills are shown in Plates VII, VIII, IX, XX.

The earliest in this period used no water at all. The first introduction of it was that thrown from a puddle by a small tin (Plate XI). The first real step forward was made when the spray was introduced at 
about the turn of the century. This was an important improvement (Plate XII). Often the men neglected to use it, the claim they made being that they would as soon die of phthisis as of pneumonia and rheumatism. The miner had to work closely with his machine, and as the spray made a wide discharge of water it was difficult if not impossible to keep dry.

A culprit amongst the rock drills was the air-feed stoping machine in its hand-rotated model (Plate XXIX). As the holes drilled were upwards the miner was covered in dust when drilling dry and in muddy water when drilling wet with the spray. The machine had to be continuously rotated to and fro by the hand lever to maintain a round hole. This form of drill was commonly called by miners 'the widow maker.' During the next period, the machine became automatic in action and as free from dust as any other (Plate XXX).

Mention was made above of the great emigration of miners from Cornwall. As a result of the appalling health conditions under which they were compelled to work overseas many hundreds returned to Cornwall every year to die of ' miners' complaint.' The pallid face and the hard, short cough was a well-known sight and sound in the Cornish towns.

During the worst period on the Witwatersrand in the first few years after the Boer War it was estimated that the length of active life of a miner was from 3 to 5 years. The record of those days and the subsequent improvement is fully set out in the book printed at the Government Press in Pretoria in June 1937 under the title of 'The Prevention of Silicosis on the Mines of the Witwatersrand.' It is therein shown that of the 60 years of mining there, there was some recognition of silicosis for nearly 50 .

No serious notice was taken of the dust hazard until 1902. By that time it had become most grave. All drilling was done by European miners, who remained continuously on the mines and did not go home from time to time to kraals on the open Veldt, as did the natives who were used as spanner boys first and as drill runners later.

The number of rock drills at work was rising rapidly; by 1896 over 1,000 were in use, and the figure had risen by 1899 to over 2,000. Blasting took place at any time during the shift, and all broken rock was shovelled dry. In 1902 a report from the Government Mining Engineer drew attention to what was happening. He said that of 1,177 rock drill men employed on the Rand before the Boer War, 225 were known to have died of phthisis. Even up to 1937, 70 per cent of silicosis on the Rand occurred in men who had been employed on machines. The Miners' Phthisis Commission, which sat in 1903, strongly advocated that water should be used and that ventilation should be improved. It was not for many years that these recommendations were given real effect.

\section{Period V.—1912 to 1945}

Rock Drills.-During this period the problem of silicosis was taken firmly in hand, first in South Africa and then later in practically all countries of the world. A great advance was made in the prevention of the formation of dust during drilling operations by the introduction of the Leyner Drill. John George Leyner, of whom a photograph is given in Plate XIII, was the outstanding mechanical genius of the Rock Drill Industry. Almost every drilling machine working to-day operates under the principles which he introduced. Earlier machines used a piston reciprocating in a cylinder having a piston rod projecting through the cylinder cover. The drilling steel was secured in a chuck attachment on the end of the piston rod. Thus, as the piston reciprocated the drill steel was thrust forward to strike a blow on the rock face and then withdrawn in preparation for the next blow. The hole was started with a drill steel of about $2 \mathrm{ft}$. in length, which was replaced by longer steels as the depth of the hole increased. The normal depth drilled was $6 \mathrm{ft}$. The diameter of the cutting edge was reduced in each succeeding steel to obtain the necessary clearance. It will be appreciated that a large weight had to be reciprocated at every blow, and thus the number of blows per minute rarely exceeded two or three hundred. The weight of the drill itself was about $350 \mathrm{lb}$. Leyner brought to practical success the hammer drill principle, which had been experimented with before his day. In this design the drill steel is held loosely in a chuck attached to the cylinder itself, and a piston inside the cylinder reciprocates freely and strikes the blows on the end of the drill steel. A much higher rate of striking, of the order of 1,500 blows per minute, is obtained. A lighter rock drill becomes possible, and the friction caused by the reciprocation of the drill steel in the hole being drilled is avoided. An advantage of the reciprocating principle was that the steel on its return stroke tended to throw out dust and chips of rock from the hole. The stationary drill steel of the hammer principle did not do this.

(Note: A study of plates Nos. VII and XV will show the difference in general construction.)

Leyner was born on his father's ranch in Left Hand Canyon, Boulder County, Colorado, on August 26, 1860 (Compressed Air Magazine). His father, of German descent, was a native of Dachenheim, 


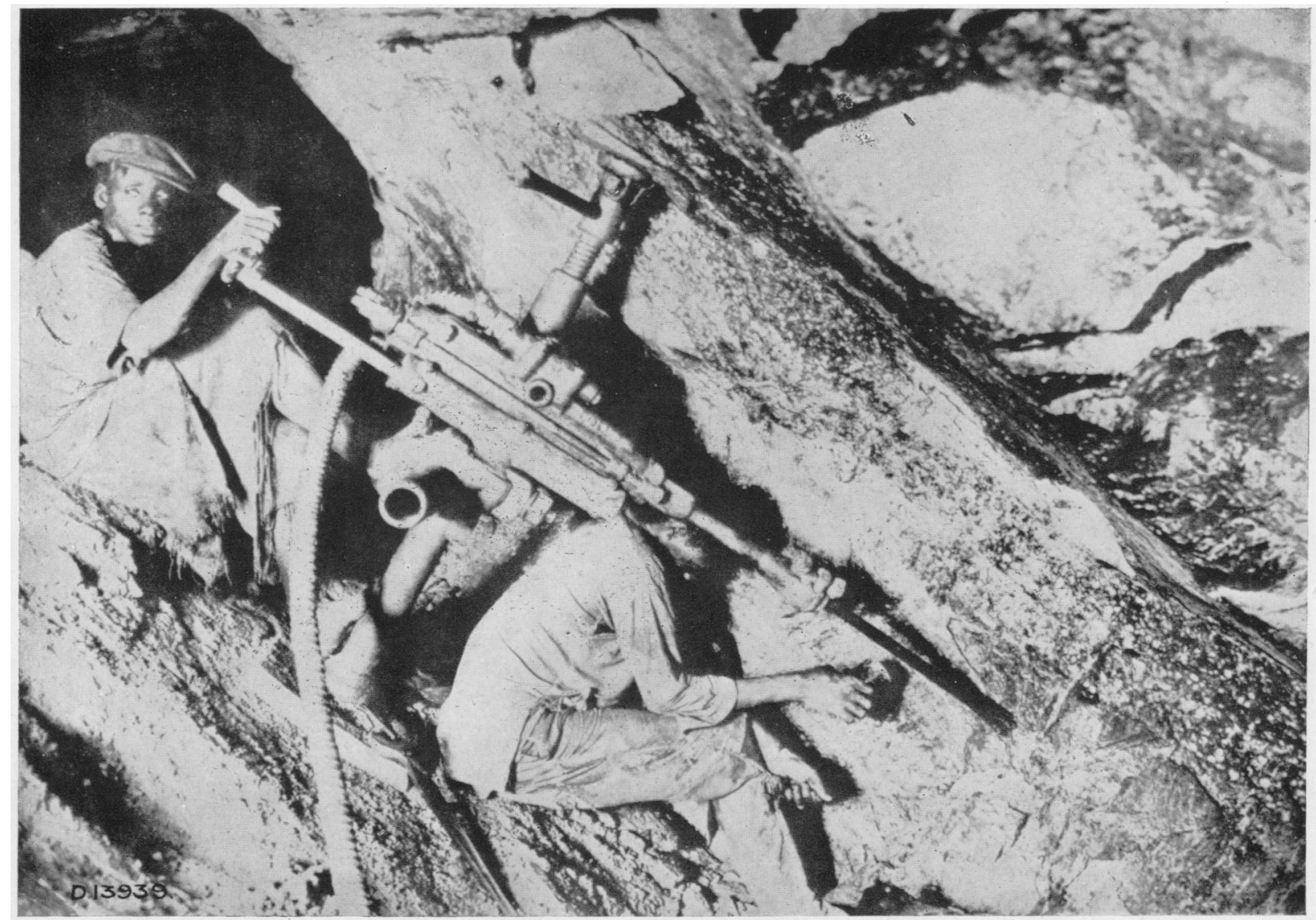

Plate XI.-Early method of introducing water into hole.

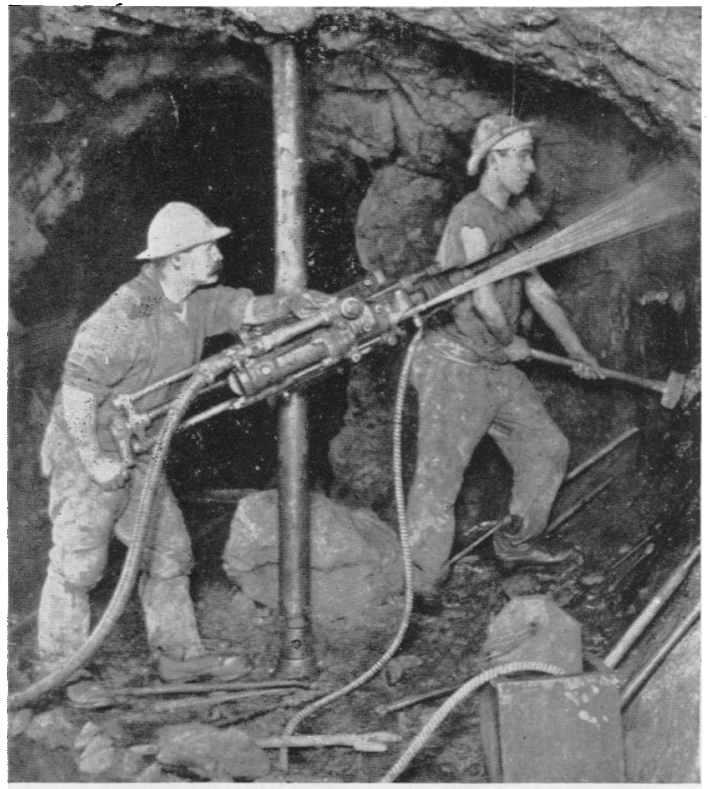

Plate XII.-Rock drill of 1902 with spray-drifting.

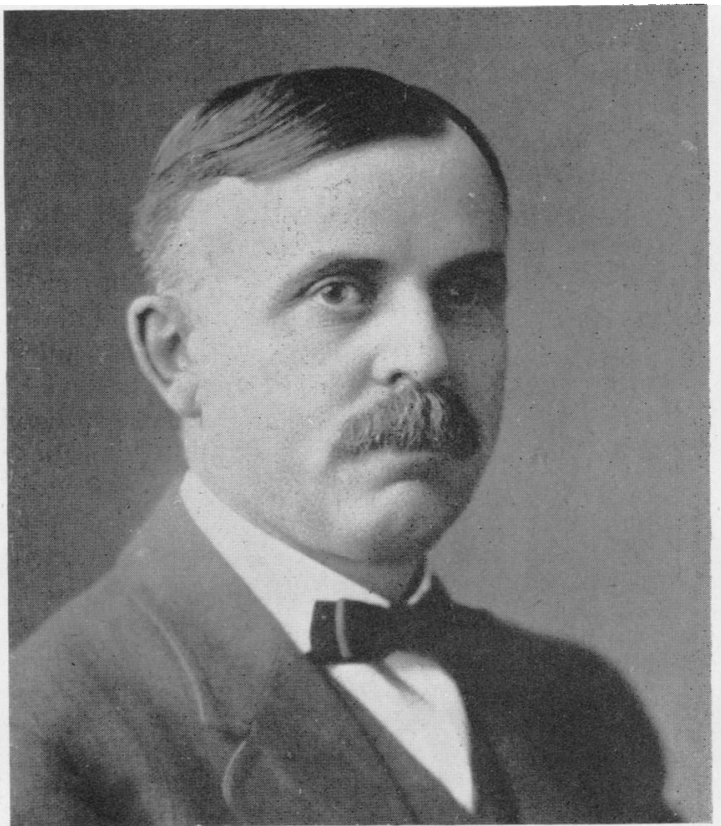

Plate XIII.-J. G. Leyner. 


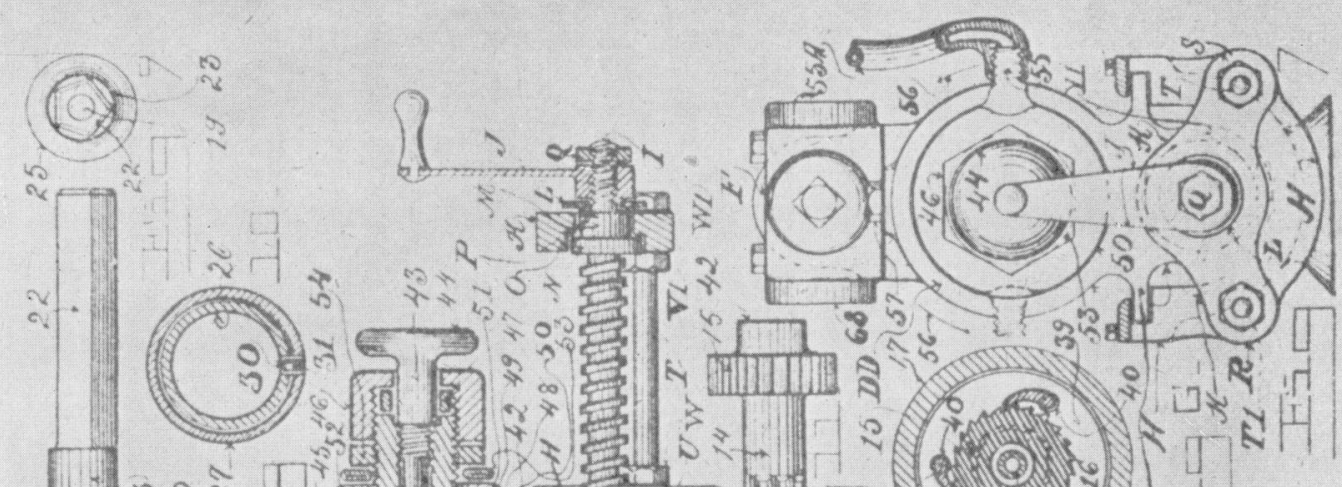

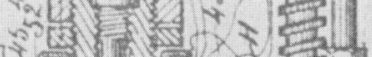
จ 2 v 1 ( $\operatorname{lin}^{2}$

6) (a)

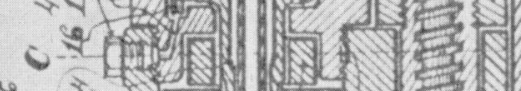

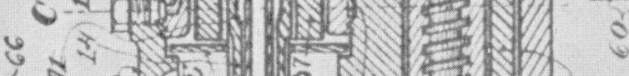
6.ง

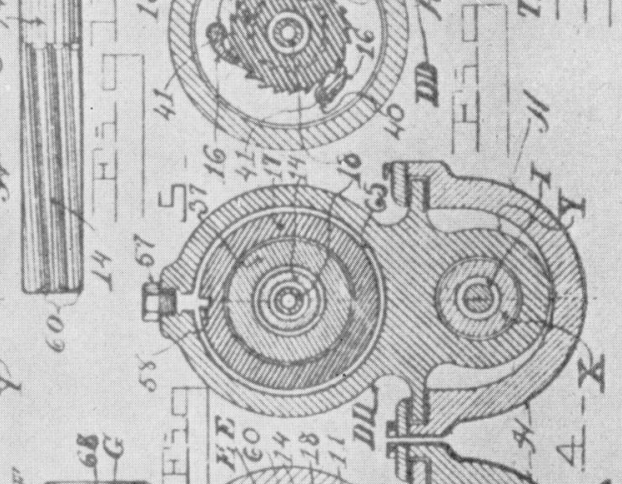
ता जक्षा $\checkmark$. 3
3
3

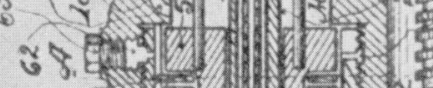

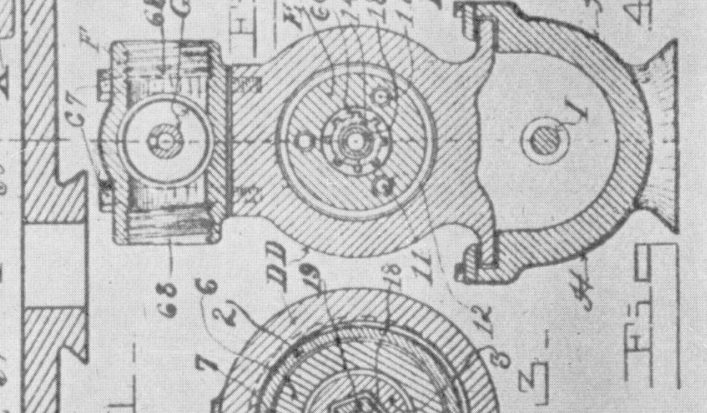
a -1 - 1 S 0] 0 - 0 (1)

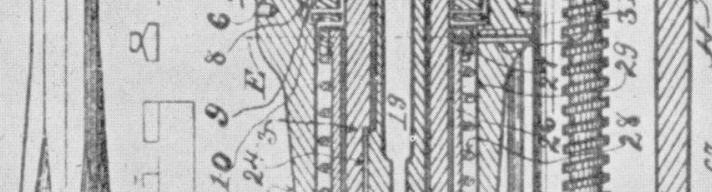

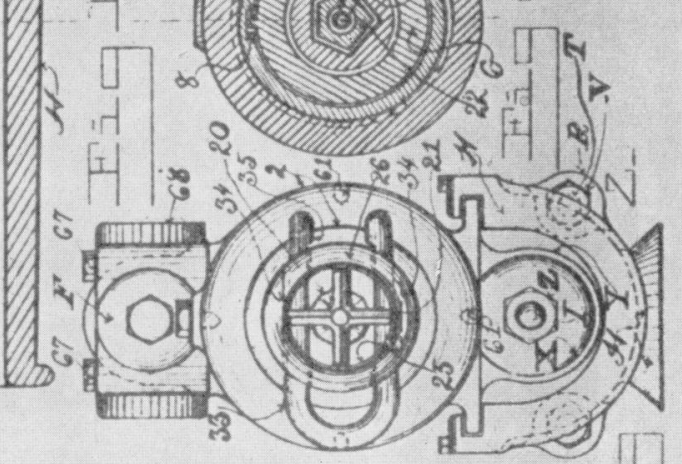

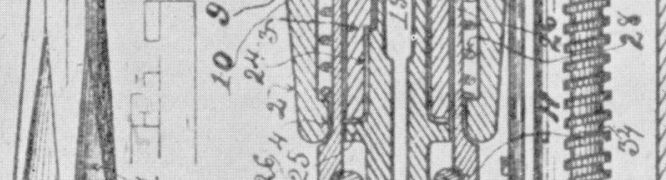

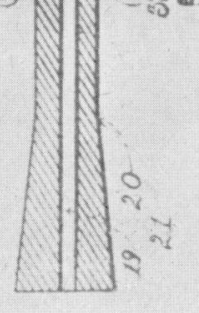


Germany. His mother came from Dutch stock and was born in Pennsylvania. John George was the eldest of seven children. He attended rural public schools and spent the rest of his boyhood years working on the family farm. The only phase of farming that interested him was the limited mechanical equipment that was then in use, and it was but natural that he should turn to pursuits more to his liking. In 1883 he obtained engineering employment with the Jackson Mining and Milling Company at Black Hawk, Colorado, one of the boom camps of Colorado's gold-mining industry. In 1891 he acquired a small machine shop and foundry in Denver, Colorado. As it was devoted chiefly to the repairing of mining machinery, it was undoubtedly there that he laid the groundwork for his later activities. Rock drills held great interest for him from the start, and he began suggesting improvements on existing models that came into the shop for repairs. After two years, in 1893, he designed a piston drill and began manufacturing it. Although the drill was similar to others on the market, it met with considerable success, for in 1894 Leyner moved to larger quarters. Shortly afterward - the exact time is not known-he began developing a hammer drill. Meanwhile his piston drill continued to be popular.

The few drawings of Leyner's first hammer drills that are still available indicate that his ideas were well crystallized by 1896 and departed considerably from the prevailing practice. He discarded the rifle-bar rotation that was used on piston drills, but subsequently had to revert to it. By the early part of 1897 his drill had reached the point where he decided to put it on the market. He sold about 75 of them, all of which were designed to blow a blast of air through a hollow or channeled drill steel for removing rock cuttings from the hole. After these drills had been in use a short time, workmen refused to run them because they raised so much dust. As Leyner had guaranteed them, he took them back even though it was a financial blow that put him on the verge of bankruptcy. He was convinced, however, that he was on the right track and would not admit defeat. He set to work to find a solution of the dust problem, and finally decided to pass water along with air through the drill steel. The drills were modified accordingly and returned to the field. As the water allayed the dust, there were no further complaints, and the new drills quickly began to show their superiority over other existing types. Leyner obtained a patent on the commingling of air and water in the drill steel; and this patent later proved to be his most valuable asset (Plate XIV). His drills were lighter than piston drills, drilled faster, and were more efficient. In addition, his right to the exclusive use of air and water for removing cuttings from the hole gave him a tremendous advantage over any competitors that also produced a hammer-type machine.

It is impossible to-day for one to appreciate fully the difficulties Leyner encountered in connexion with the introduction of his new type of drill. All drill steel previously employed had been of the solidbar type. In order to make this drill useful, it was necessary for Leyner to incorporate in the drill steel a tube or hole of some sort through which air and water could be passed. As no method of manufacturing hollow drill steel was then known, all sorts of schemes were tried. Not only Leyner but numerous others attempted to find a satisfactory solution of the problem. He prepared drawings and specifications for such steel in 1898 , but none of the mills would make it for him. Thereupon Leyner began to manufacture his own hollow drill steel. He machined bits and forged shanks out of tool steel, drilled a hole through them, and, after scarfing the ends, welded them to the opposite ends of a length of staybolt iron. The result was a composite member with a central hole through it that accomplished the desired purpose, and Leyner continued to make steel in this manner for more than ten years. One of his former employees recalls that after one man had welded on the two end pieces another man would attempt to break them off with a sledge hammer. If they remained intact the steel passed inspection and was shipped.

In 1902 his business had again outgrown its quarters and had attained such a size that Leyner decided to incorporate it under the name of the J. George Leyner Engineering Works Company. At this time the concern was building two models of the 'Water Leyner' drill-the 5A and the 5B. Leyner had discontinued making piston drills in 1900 , having become convinced that the hammer drill was the better type. Leyner continued to turn out new models of his drifter drills from time to time, and in 1910 was offering Nos. 7, 8, and 9 to the trade. They were all similar in design and differed only in weight. He had also developed a line of stoping drills. The Leyner drills of that day would not compare favourably with corresponding types built to-day, but then they were the most efficient units obtainable and represented a distinct advance over the piston-type drills.

In 1912 the Leyner Company entered into an agreement with Ingersoll-Rand Company whereby the latter became the sole distributor of Leyner products and was granted the exclusive right to build rock drills under Leyner's patents (Plate XV). 


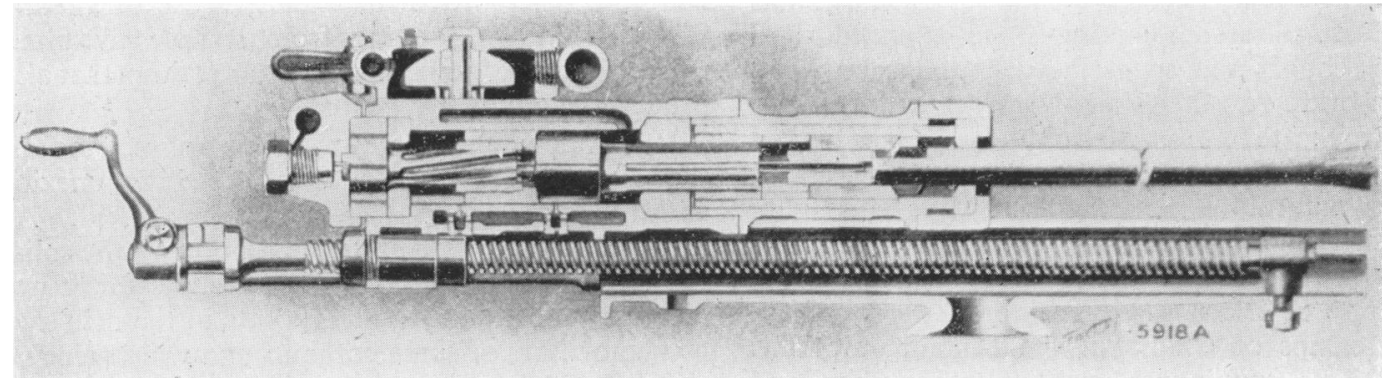

PLATE XV.-Sectional view of Leyner-Ingersoll drifter drill of 1912.

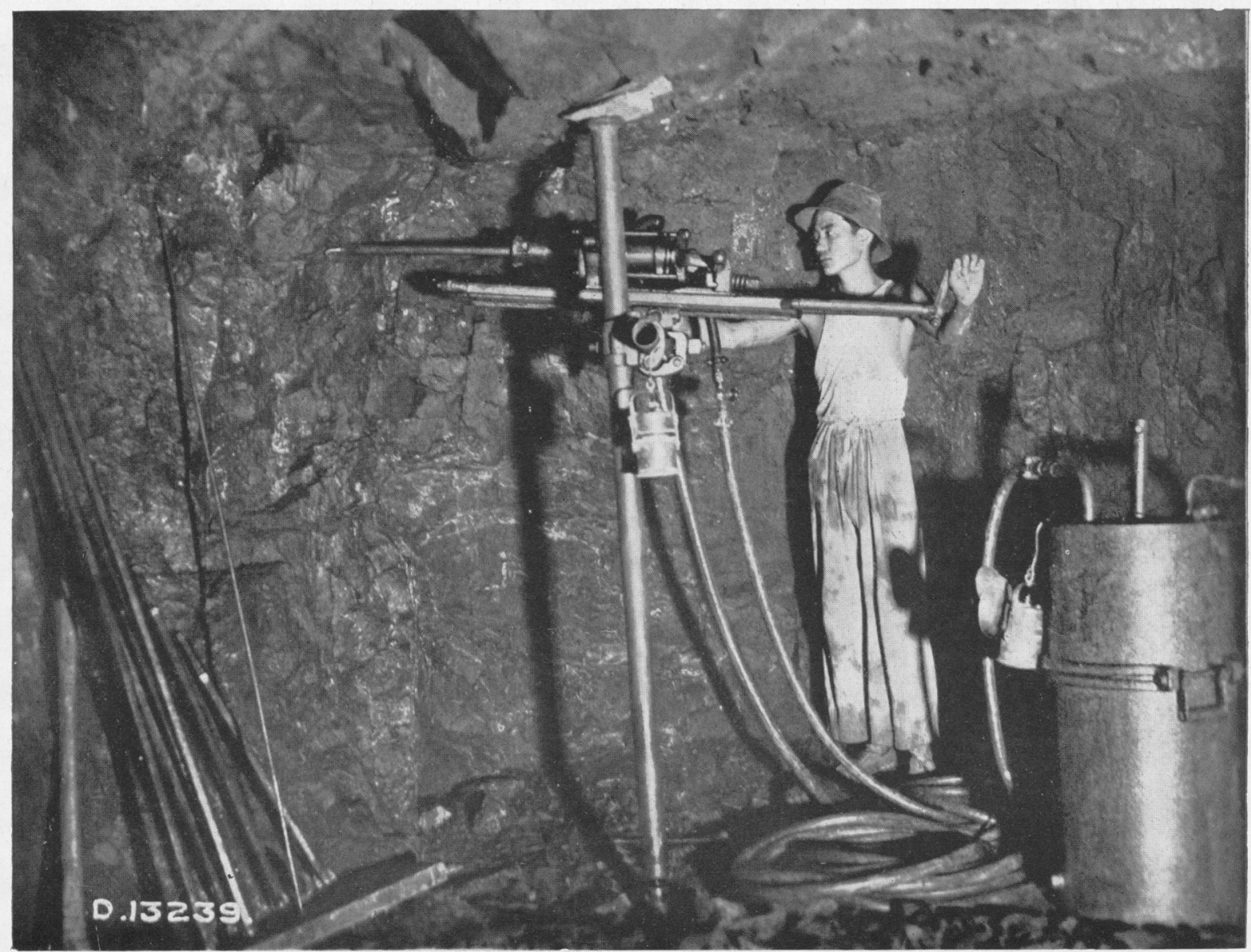

PLATE XVI.-Cradle-mounted hand drill drifting in a Malayan mine. (Note tank for supplying water under pressure.) 


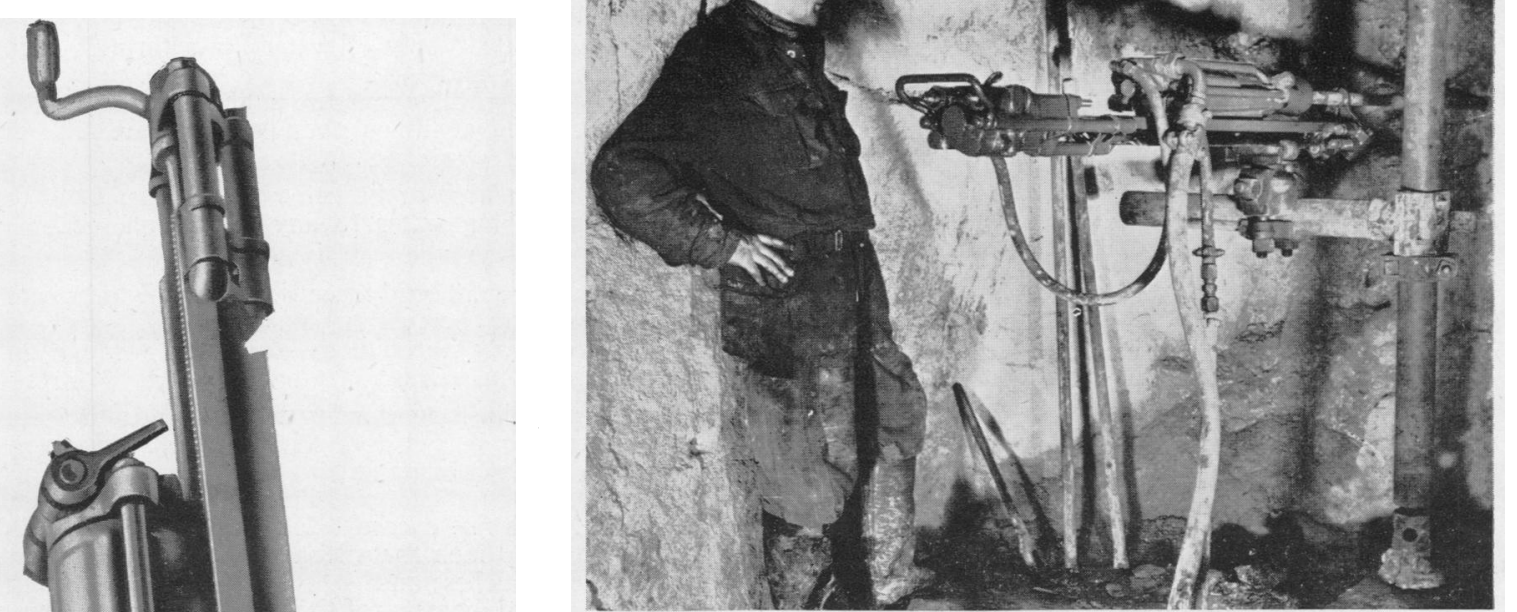

Plate XVIII.-Automatic vented drifter drill of 1945 with single control for air and water.

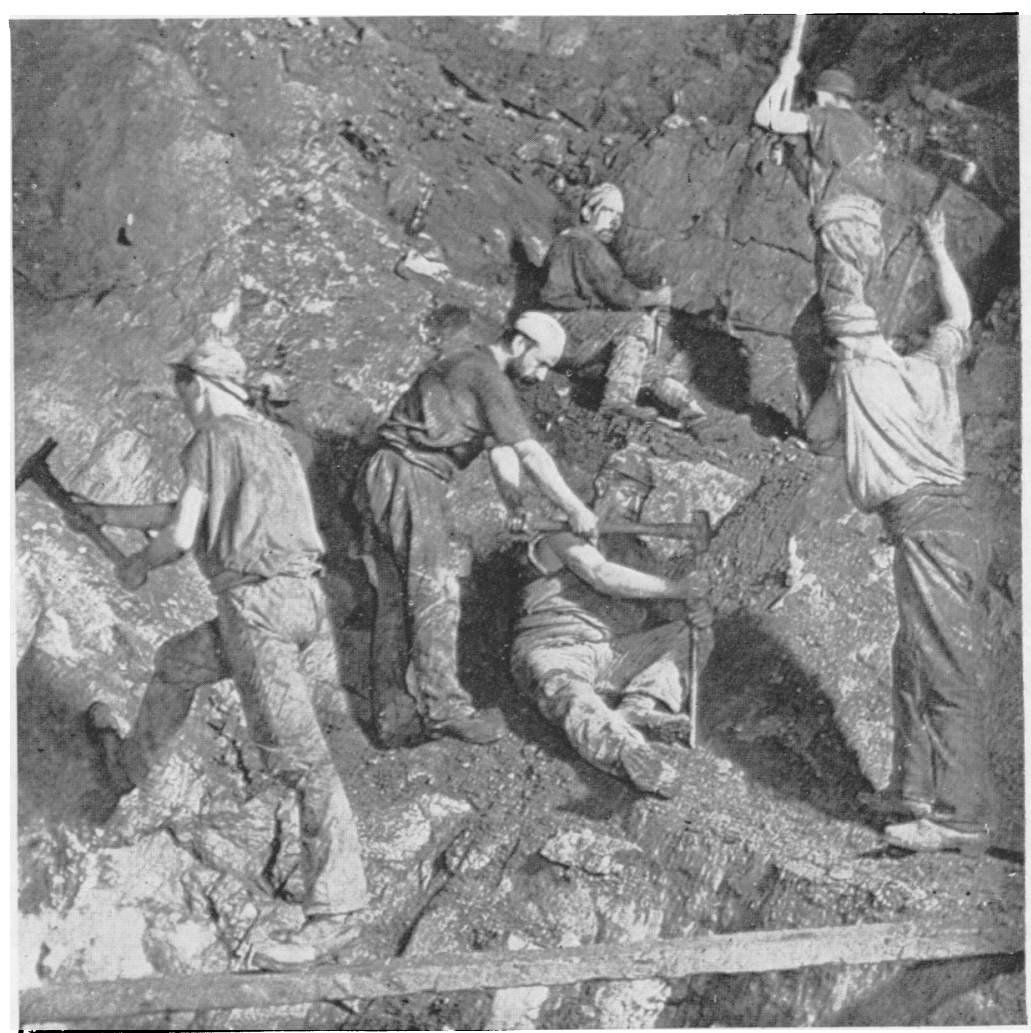

PLATE XIX.-Hand drilling underhand stoping. 
On August 3, 1920, Leyner was injured in a motor-car accident, and died two days later, on August 5, three weeks before attaining the age of 60 .

In 1913 the Leyner patents covering water through the hollow tube and so through the hollow drill steel terminated, and thereafter this type of rock drill became, by degrees, standard in all mining countries of the world. Although the Leyner drill caused a great reduction in dust, yet it will be noted that in his patents-and his drills followed the patentswater and air passed down the drill steel, the assumption no doubt being that water would not keep the hole clear of itself. It is interesting to note that all other rock drill manufacturers imagined the same thing and, therefore, were unable to use the water tube with hollow drill steel. The modern vented machine as it is made to-day would have been as free from the Leyner patents as it undoubtedly is freer from the making of dust. As will be shown later, no air may pass down the drill steel under recent regulations and so the danger of bubbles containing grains of dry dust being released into the atmosphere is eliminated.

As the story of dust preventive measures is principally laid on the Witwatersrand, we will return to a further consideration of the South African Government publication of 1937. In 1919 the Phthisis Prevention Committee laid down that dry drilling should be prohibited, only axial water-feed (Leyner type) drills to be allowed in raising and boxholing. Other drills must have a water pipe in the hole, the working places must be wetted down from a distance of at least twenty-five feet from the hole. In 1921 there was a total prohibition of drills designed to pass air only down the steel, no matter in which part of the mine they were used. This regulation resulted from research, which showed that the amount of dust liberated by the drills varied almost directly with the amount of air going down the hollow steel. In 1926 a further advance was made, by the prohibition of the use of machine drills having internal water tubes without release ports being provided in the front head of the drill. In 2.5/8-in. cylinder diameter drills, the normal standard, the minimum area of the release ports must be not less than 0.3 of square inch (Plates XXIV and XXV).

The Regulations as they were amended to August 1944 are as follows :

'(1) in drilling a hole no person shall use or cause or permit to be used any percussion machine drill unless

(a) the drill steel with which the machine is equipped is provided with an axial hole not less than onequarter of an inch in diameter throughout its whole length when the diameter of the drill steel is one and one-eighth inch in diameter or over, and not less than three-sixteenths of an inch in diameter throughout its whole length when the diameter of the drill steel is less than one and oneeighth inch; and

(b) an adequate supply of water flows through such drill steel; and

(c) the working water pressure at the machine drill is maintained at fifteen pounds per square inch or over;

(2) no branch hose or branch pipe shall be fitted to any hose supplying water to any percussion machine drill;

(3) no person shall send or cause or permit to be sent underground any percussion machine drill which is designed to supply water to the drill steel through an internal water tube unless

(a) such machine is provided with front-head air release ports of a design approved by the Government Mining Engineer; and

(b) the diameter of the axial hole in the piston, when new, does not exceed 0.262 inch and is not less than 0.260 inch for a length of at least two and one-half inches; and

(c) the external diameter of the water tube, when new, is not less than 0.255 inch, and the internal diameter of the water tube is not less than $0 \cdot 156$ inch; and

(d) the machine drill is fitted with a water tube of such length that, when drill steel of the type supplied for use with the said drill underground is inserted into the chuck to its fullest extent, when the machine is not operating, the water tube either enters the axial hole in the shank of the drill steel for a distance of at least one inch or, alternatively, the end of the water tube is not less than onequarter of an inch and not more than one inch short of the shank end of the drill steel;

(4) (a) no person shall block or otherwise obstruct any of the front-head release ports provided in terms of paragraph $(a)$ of sub-regulation (3) of this regulation, and no person shall operate or cause or permit the operation of any machine drill if the front head release ports so provided are partially or totally blocked or otherwise obstructed;

(b) no person shall supply for use in, or fit into, any rock drill a water tube which does not comply with the provisions of paragraphs $(c)$ and $(d)$ of subregulation (3) of this regulation;

(c) no person shall wilfully damage or alter a water tube supplied for use in a machine drill;

(d) any ganger in charge of drilling operations, who knows or has reason to suspect that the water tube in any machine drill under his control has become damaged or is defective, shall immediately examine such water tube and if it is found to be damaged or defective he shall replace it with an undamaged water tube before drilling operations are resumed with any such machine drill. It shall be the duty of any person who knows or has reason to suspect that the water tube in a machine drill is damaged or defective to report the matter immediately to the ganger responsible for the operation of the machine drill;

(5) (a) no new type or make of machine drill may be used without the prior approval of the Govern- 

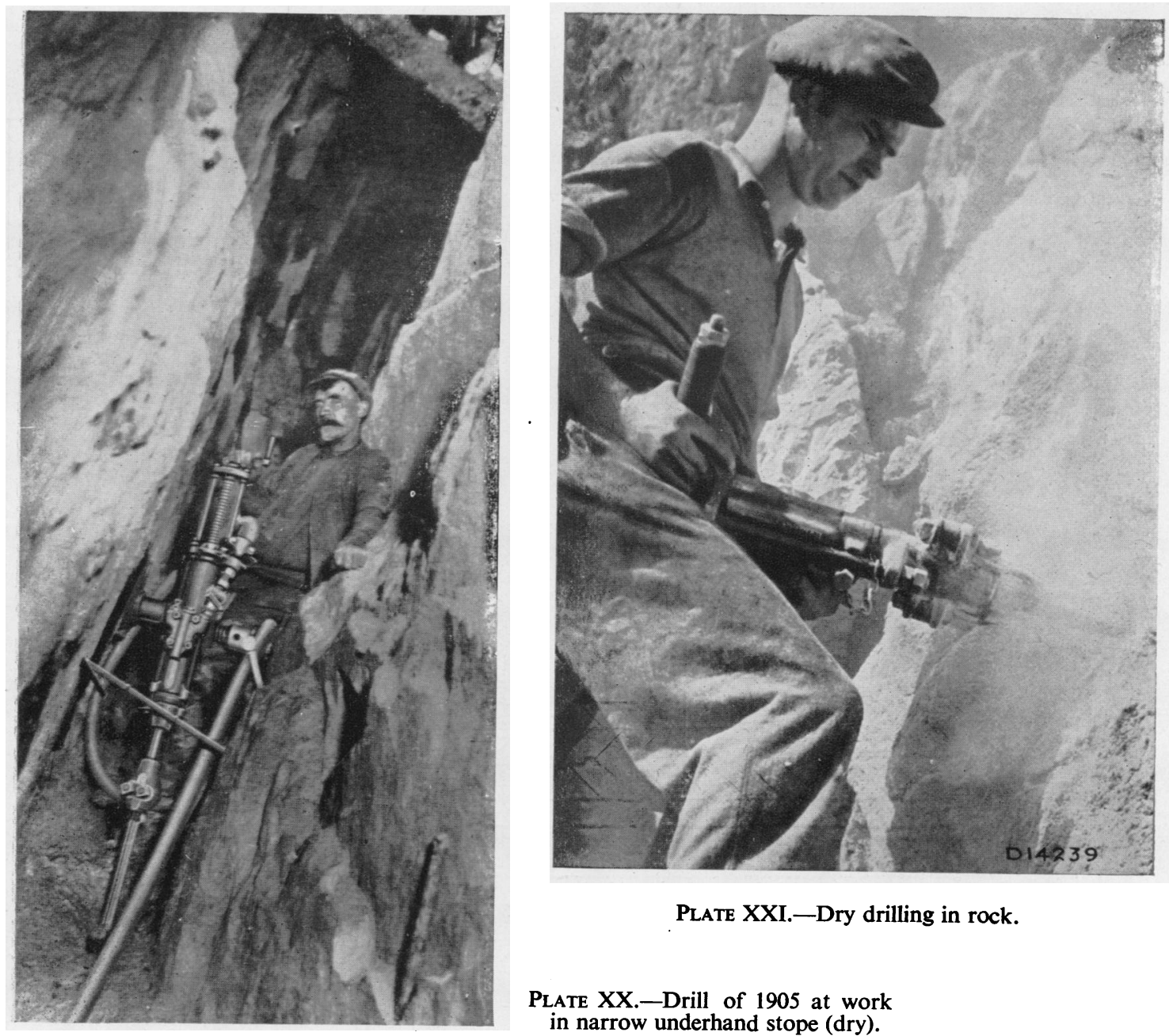

Plate XXI.-Dry drilling in rock.

Plate XX.-Drill of 1905 at work

in narrow underhand stope (dry).

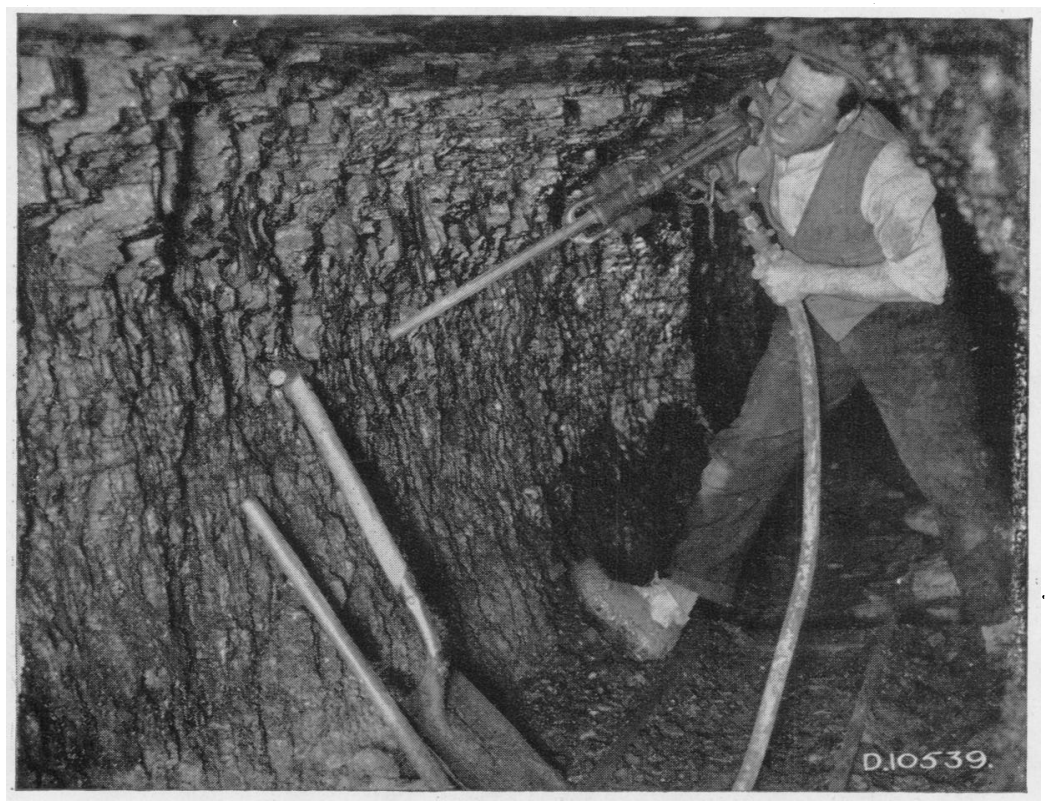

Plate XXII. -

Dry drilling in soal. 


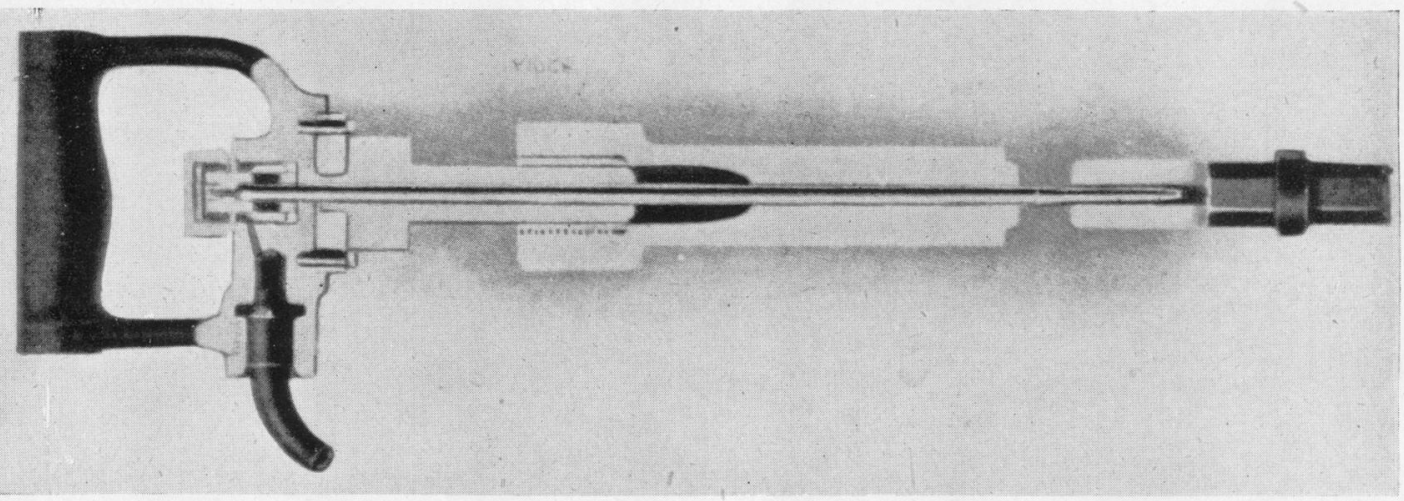

Plate XXIII.-Water tube assembly, hand-held drill.

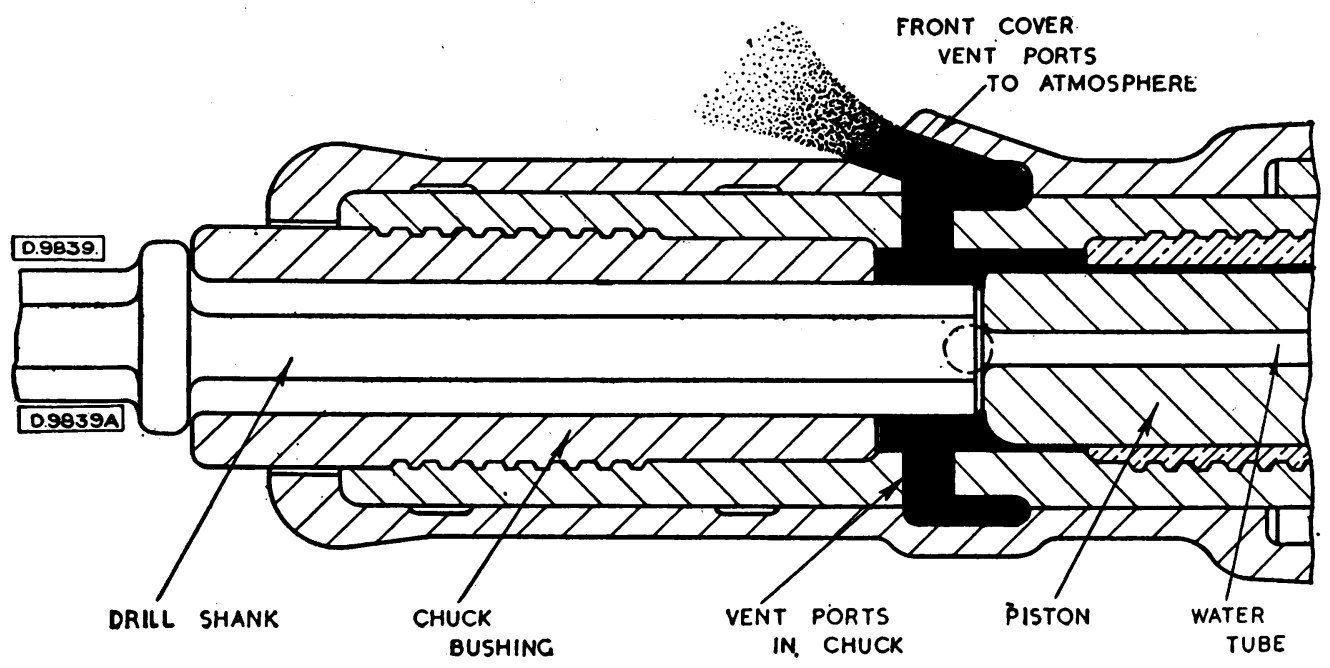

PLATE XXIV.-Modern vented front head.

ment Mining Engineer, or may be continued in use unless that approval is ratified by him within one year, or such longer period as he may determine, and after at least twenty (20) of the machine drills so provisionally approved have been in regular use on scheduled mines, or mines to which this sub-regulation has been applied in terms of sub-regulation (2) of regulation 166, to his knowledge for a period of six months;

(b) the Government Mining Engineer may prohibit the use of any type or make of machine drill in use on any scheduled mine. Such prohibition shall take effect after a date to be specified by the Government Mining Engineer, such date to be not less than six months after the date of notice of prohibition;

(c) the Government Mining Engineer shall not prohibit the use of any drill under paragraph $(b)$ of this sub-regulation unless there is evidence that the drill to be prohibited seriously and materially endangers the health of workmen and until he has consulted the employers and the workmen concerned.

(d) the Government Mining Engineer may carry out any inspection or test of any machine drill, device, or attachment at a cost to the owner, manufacturer, or agent of a sum not exceeding thirty pounds $(£ 30)$ for each complete test:

(e) any employer and any owner or manufacturer of a machine drill or his agent may appeal to the Minister against any refusal by the Government Mining Engineer to approve or to ratify the approval of a new type or make of machine drill, or against any prohibition by him of any existing type or make of machine drill, and the decision of the Minister shall be final and conclusive;

(6) no person shall use or cause or permit to be used any hand-drill, moil or similar tool, except in sampling, 

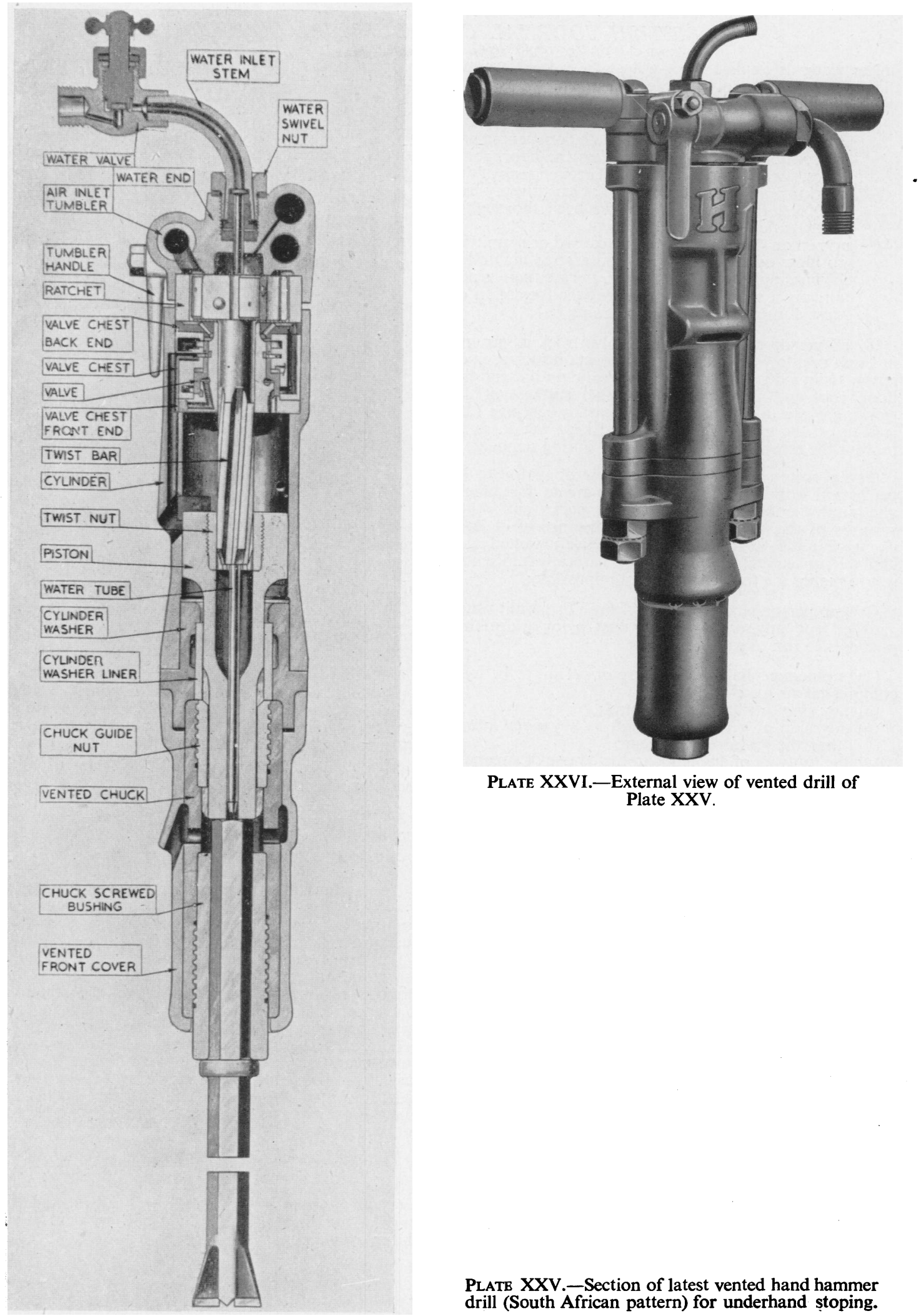

w

들

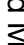

잉

$\overrightarrow{\mathrm{F}}$

음

क

$\stackrel{\mathbb{\Omega}}{\Omega}$

क

$\vec{\circ}$

$\overrightarrow{\vec{\omega}}$

จิ

吾

I

옥

c

일

$\overrightarrow{0}$

뭉

三

ڤँ

$\stackrel{8}{8}$

윽

쿵

ণิ

국

음

ㅇํํ

음.

N

N

PLATB XXV.-Section of latest vented hand hammer drill (South African pattern) for underhand stoping. 
unless water is applied or a wet swab is used around the drill at the collar of the hole so as to allay the dust;

(7) (a) no person shall commence or continue to drill any hole, or cause or permit such commencement or continuation of drilling unless the floor, roof, sides, packs, other surfaces, and broken rock of the working place, to a distance of at least twenty-five (25) feet from such hole, have been thoroughly wetted and kept wet;

(b) no person shall blow out or be caused or permitted to blow out any hole with compressed air unless he has applied sufficient water, in case there is not already a sufficiency, to prevent the formation of dust during the process of blowing out;

(8) no person shall move any broken rock or ground or cause or allow the same to be removed, if such rock or ground is in a dusty condition, unless and until it and the floor, roof and sides, packs and other surfaces of the working place to a distance of at least twenty-five (25) feet have been effectively wetted and kept wet so as to prevent the escape of dust into the air during removal;

(9) no person shall perform or cause or permit to be performed work of any kind liable to create dust unless and until the floor, roof and sides, packs and other surfaces of the working place to a distance of at least twenty-five (25) feet have been effectively wetted and kept wet, unless such working place is naturally sufficiently wet to render the formation of dust impossible;

(10) no person shall negligently cause or permit water supplied from any service pipe for dust-laying or drinking purposes to run to waste;

(11) no person shall use or cause or permit to be used compressed air for cleaning

(a) any skip or truck underground;

(b) any skip at a downcast shaft at any point lower than the tip in the headgear

(c) the footwall of any stope in the course of sweeping operations.'

In addition to these regulations the quality of water supplied has been investigated. If the water contains solids in suspension, any spray or fog produced by the machine may add dust to the air. Water filtering plants of sand filter beds have been installed in some mines, and a substantial reduction in the dust produced during drilling is claimed.

Silicosis.-As regards the medical aspect, the 1937 South African publication states that much investigation has been carried out and the relationship of silicosis to tuberculosis has been considered in some detail in the light of the experience of the past twenty-five years. The fact of the occurrence of a simple silicosis is upheld. The distinction between a silicosis of simple type and a silicosis of infective type originally based upon clinical and pathological grounds has recently obtained interesting confirmation in the following connexion. In the past few years a good deal of work has been published reporting on the recovery of mineral residues from the lungs of those who have died of pneumono- coniosis, and most observers report that they have found no precise relation between the pathological reaction and the amount of mineral residue recovered. It is clear from the descriptions that much of their material was what would have been called silicosis of infective type. South African experience has been that in the case of simple silicosis 'the degree of reaction is in general proportion to and is limited by the amount of siliceous dust retained in the affected lung.' In the case of silicosis of infective type, including 'tuberculo-silicosis' there is no close relation between extent of lesion and amount of mineral residue covered. This, after all, is what any pathologist would expect. The report states: 'We are satisfied that we meet with a type having a direct relation between mineral residue and extent of lesions which has the clinical and postmortem characteristics of a simple silicosis, and also with a type exhibiting no such close relation, which has the clinical and post-mortem characteristics of a silicosis of infective type.'

In conformity with these conclusions a brief account is given of the general characters which serve to distinguish the three clinical and pathological types of silicosis met with, namely:

(1) 'Silicosis of simple type' in which the condition present is, apart from the accompanying bronchitis, practically that of a simple nodular dust fibrosis which has undergone no significant modification by infection.

(2) 'Silicosis of infective type' in which lesions of the mixed silicotic and infective characters referred to form a prominent feature, but in which there is no evidence of the presence of active tuberculosis, and

(3) 'Silicosis with tuberculosis' in which a silicotic condition is associated with active tuberculosis.

Finally, it is shown that, when taken as a whole, the prevalent form of silicosis met with nowadays presents three general characteristics:

It is a condition which on the average in those who contract it requires for its production a cumulative duration of some 17 years' previous exposure to our underground conditions.

It remains on the average intrinsically a progressive condition, although the data presented indicate that a gradual amelioration is taking place in this respect and that a considerable number of cases undergo a virtual arrest for prolonged or apparently indefinite periods.

It is, nevertheless, on the average a chronic disease. Some years ago the average expectation of life for all cases from the detection of early silicosis was found to be from 15 to 16 years. It is probably greater now. The average age at which the presence of silicosis is now detected is practically fifty years.

The medico-legal stages of silicosis recognized for purposes of compensation are the following:

(1) 'Ante-primary silicosis,' the earliest detectable stage of the disease in which disability is at most slight and may be absent. 


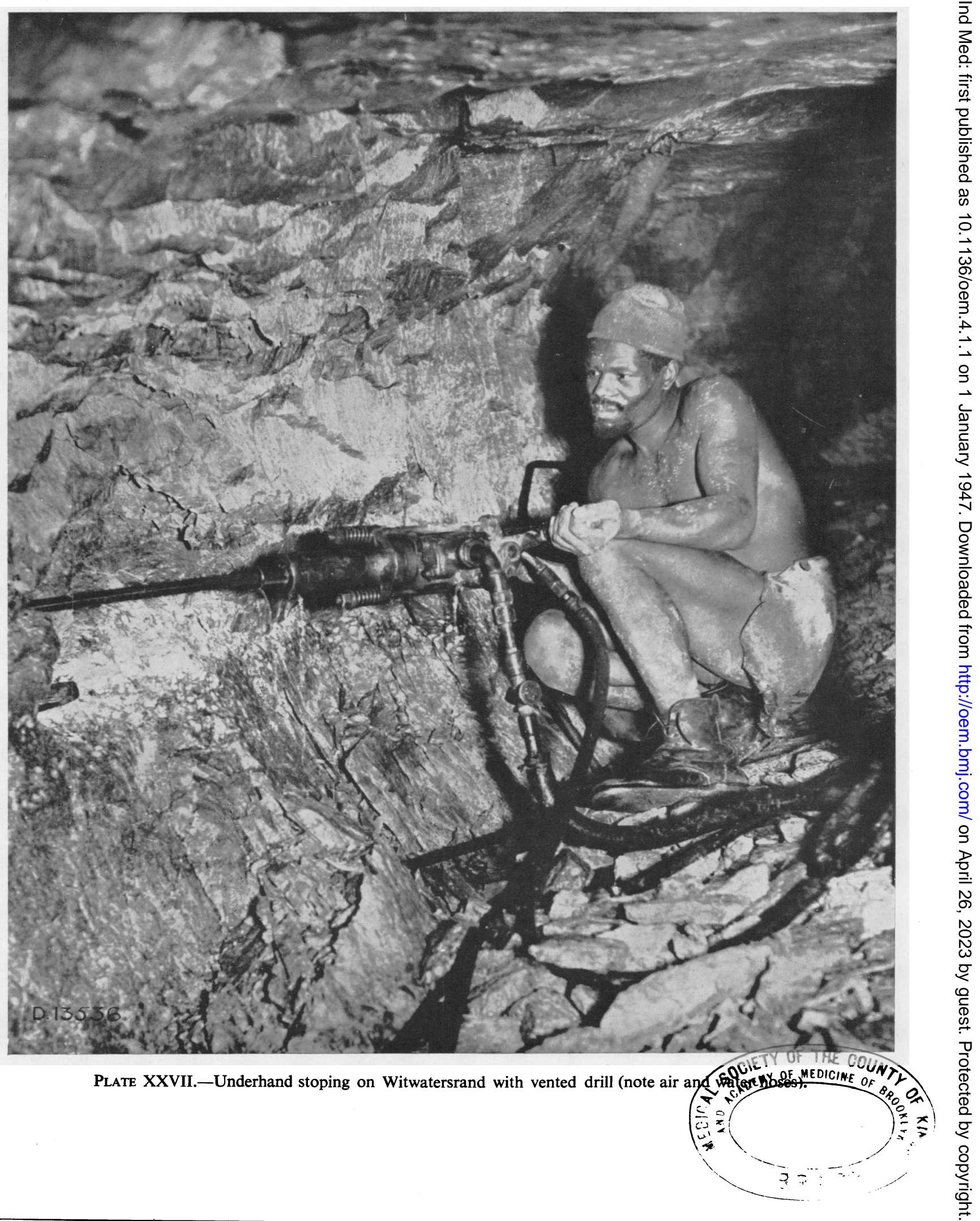


(2) 'Primary silicosis' in which there is a moderate degree of disability.

(3) 'Secondary silicosis.' This stage includes cases of silicosis with grave disability and also all cases of " tuberculosis with silicosis' in which active tuberculosis is present along with any degree of silicosis.

Before 1919 the earliest compensatable stage of silicosis was the 'primary stage,' in which a miner had to present evidence of disability before qualifying for compensation. This provision was dropped in the Act of 1919. It was not suited to circumstances in which it was the object to detect a chronic disease at a sufficiently early stage for there to be hope of its arrest. Accordingly, in that year the earliest compensatable stage recognized was the ' ante-primary stage' which was defined as the earliest detectable stage of the disease, irrespective of whether disability was or was not present. The hope that silicosis at this stage would be arrested in the absence of further exposure to dust has not been borne out. Witwatersrand silicosis is, with the qualification previously mentioned, still in the main a progressive condition. Even cases of simple silicosis are progressive up to a point and often to a very considerable degree; further sustained progression signifies infection.

It is the duty of the Miners' Phthisis Medical Bureau to carry out a systematic follow-up of all cases certified up to the stage of grave incapacitation, in order to detect any alteration in their condition which may be significant in respect of compensation. The returns of the Bureau enable one to follow the incidence rates of silicosis from 1917-18 to the present date, a period of twenty years. It is shown that whereas in the period 1917-20 the combined incidence of new cases of silicosis, and silicosis

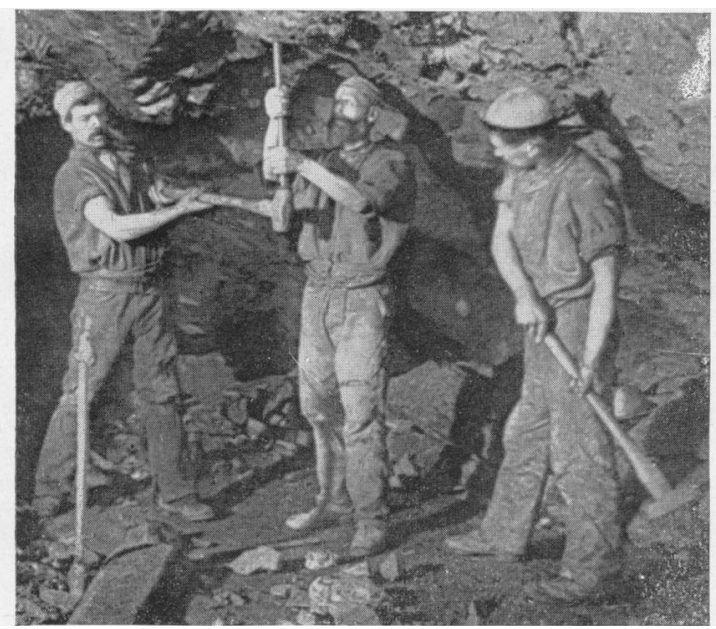

Plate XXVIII.-Hand drilling, overhand stoping.

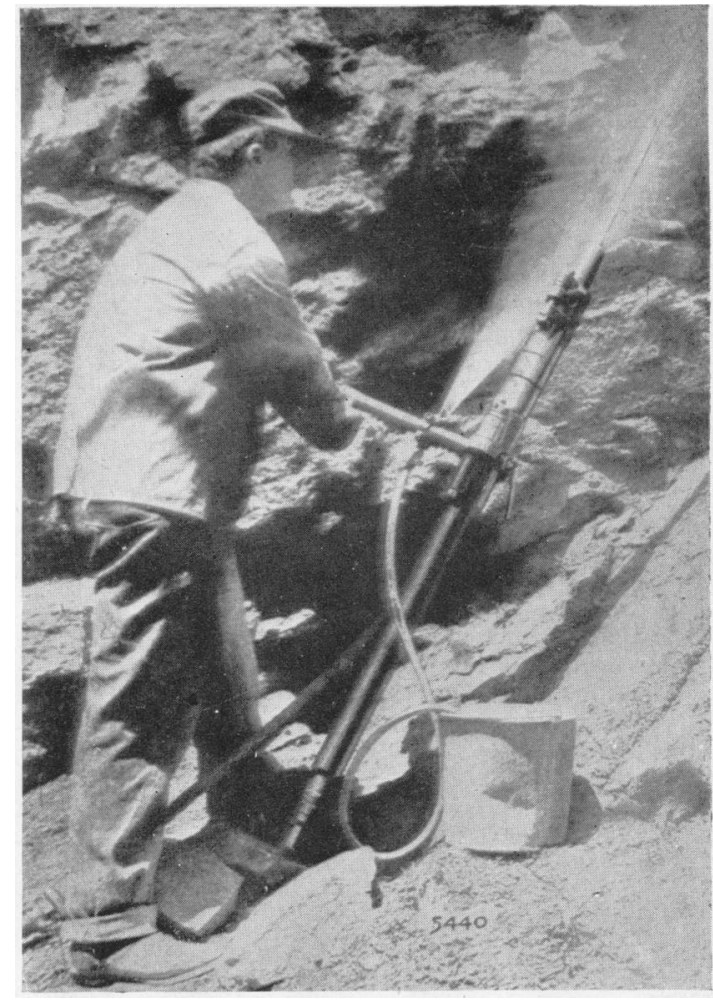

Plate XXIX.-Overhand stoper with spray.

with tuberculosis, detected at the periodical examinations of working miners was 28 per 1,000 , in 1920-23 it was approximately 21 per 1,000 , and during the past three years has averaged 9 per 1,000 . It is pointed out, however, that owing to changes in the medical standard of certification during the first half of the twenty years' period, caused in part by the introduction of compensation for the ante-primary stage in 1919, and in part by a slight further liberalization of the standard of diagnosis effected by the Bureau from 1923 to 1926 as the result of accumulated experience and improved radiographic technique, the incidence rates in these earlier years are not at all points directly comparable with those of the past ten years. The Bureau has, therefore, adopted, as a more accurate comparative measure of the liability of the working miners to contract silicosis at different periods, the method of comparing the incidence of silicosis on miners working in each consecutive year of underground service at the respective different periods. The result is shown in graphs (Plate XXXI) which show very convincingly the decrease in the liability of the working miners to 


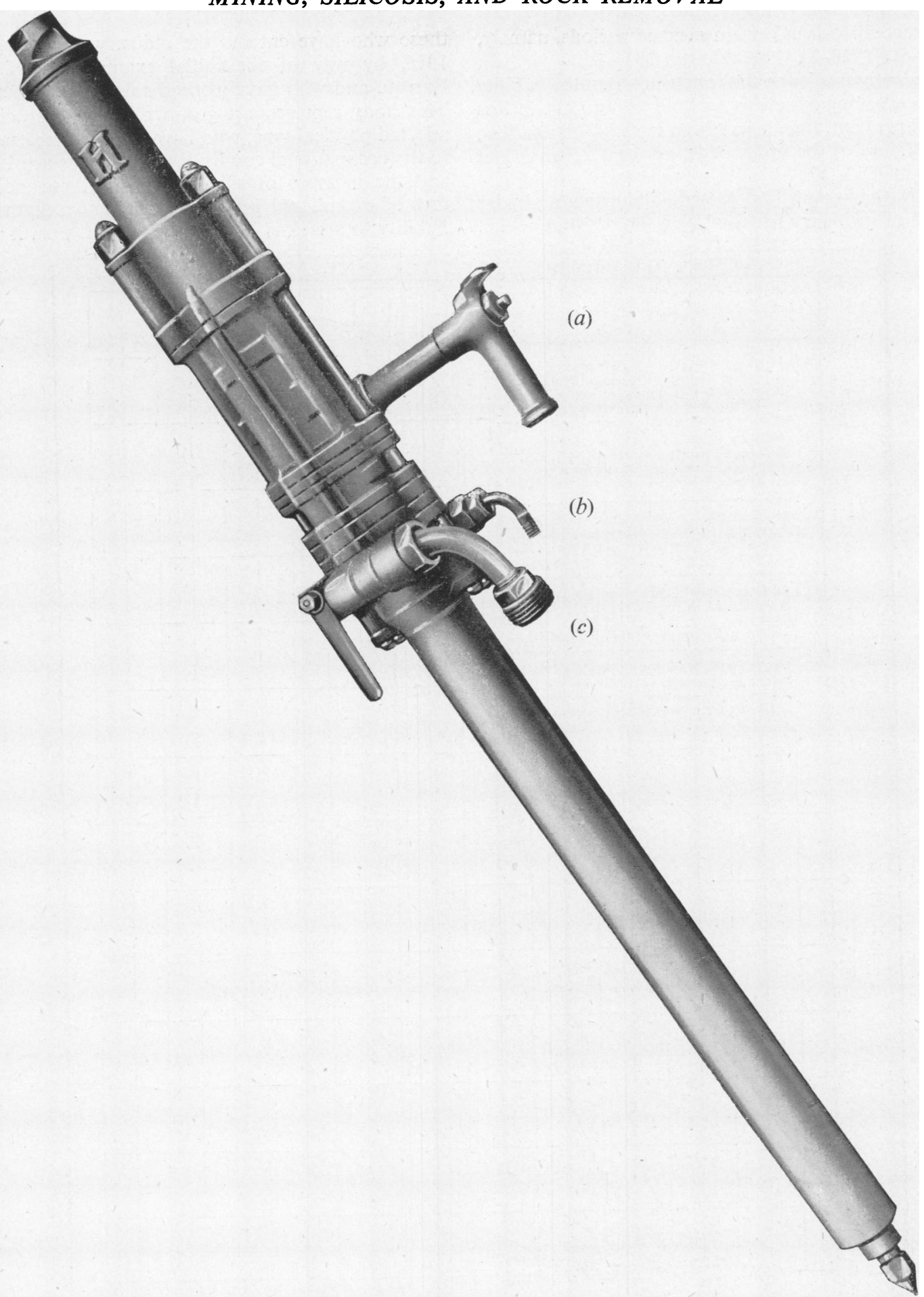

PlaTe XXX.-Automatic overhand stoper with axial water tube : (a) control handle ; $(b)$ connexion for water hose ; $(c)$ connexion for air hose. 
contract silicosis at certain selected periods, namely, 1918-20, 1920-23, 1929-32, and 1934-35.

These figures led to the conclusion that the liability of the working miners as a whole was in 1934-35 less by 64 per cent. than it had been in 1920-23, and less, by a figure of the order of 80 per cent., than it had been in 1918-20.

A further graph $\mathrm{E}$ is presented showing a similar curve of incidence for the 'New Rand Miners,' i.e. those who have entered the industry since August 1916, by way of the initial examination of the Bureau, and who have worked solely on the Rand. This body represents a group of men of specially selected physical type, who have been exposed solely to the occupational conditions obtaining since 1916, and the measure of silicosis risk of these men is thus of exceptional interest. It is shown that their liability to attack is less by 90 per cent. than it was

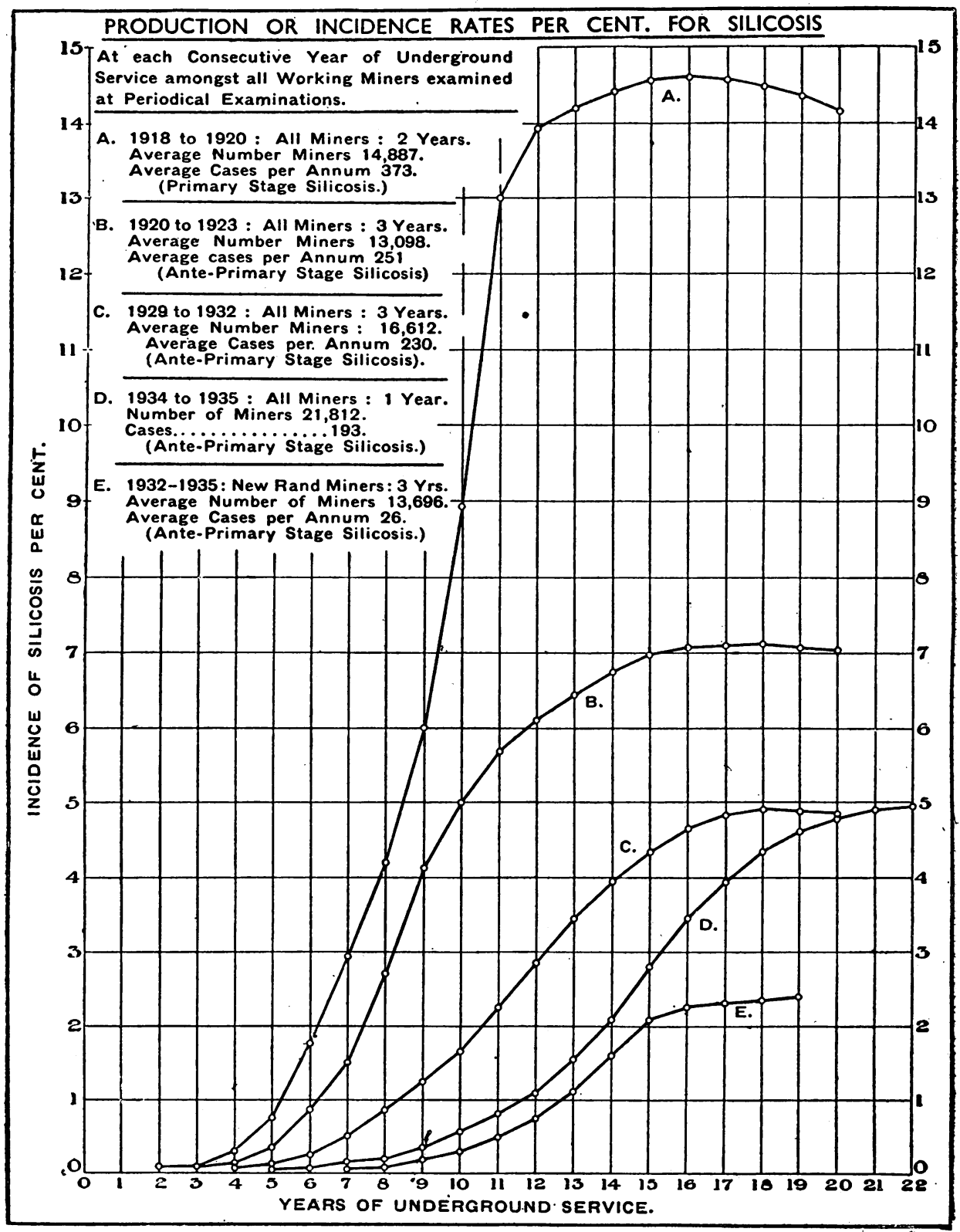

Plate XXXI.-Graphs of silicosis incidence. 
for all miners having an equal duration of service in 1920-23. Nevertheless, it is also shown that even amongst the 'New Rand Miners' the incidence of silicosis amongst those who have had 15 years or more of underground work becomes significant. In spite, therefore, of the very substantial measure of success in the reduction of the incidence of silicosis shown by the Bureau's returns, it is clear that the problem of the prevention of the disease has not yet been completely solved.

The effect of 'good housekeeping' on the Rand is very apparent. There has been an immense reduction in the average concentration of dust in the mine area.

Judging from figures published in 1902 and 1911, the concentration of dust in the mine atmosphere must in the earlier period of the industry have been very high. In the former year figures of 14 to $32 \mathrm{mg}$. per cubic metre in stopes, and of 192 and $424 \mathrm{mg}$. in drive faces, are recorded. At the first systematic dust survey of the mines in 1914-15, the general average of the dust content of mine air was at or over $5 \mathrm{mg}$. per cubic metre; from 1918-20 it was between 2 and $3 \mathrm{mg}$.; since 1924 it has consistently been approximately $1 \mathrm{mg}$. or less. This striking achievement of preventive policy has been accompanied not only by the very marked reduction in the liability of the working miner to contract silicosis which has been noted, but by a marked amelioration also in the prevalent type of the disease, by a steady extension of the duration of previous exposure to underground conditions on the part of those who contract silicosis and by a steady rise in the average age of those in whom it is originally detected.

It is emphasized that since the siliceous dust of the Rand is very obviously capable of producing silicosis the important point to determine is in what concentration and in what range of size of particle it is capable of doing so. In this respect it is stated that the evidence gained from size frequency determinations of the mineral dust recovered from silicotic lungs, and of the air-borne dust in the mines, and from experimental evidence, leads to the conclusion that the harm done probably depends chiefly on the number of particles of sizes of 2 or 3 microns and smaller which become iodged in the lungs, and that the practical problem of prevention of silicosis appears to be how siliceous particles of this size range can be prevented from entering mine air or can be removed from it. Silica dust is undoubtedly a chemico-physical irritant, but it is only significânt in the production of fibrosis if present in sufficient local concentration, and only facilitates infection by tuberculosis when its concentration is sufficient to have produced or to be capable of producing fibrosis. There is no evidence that the possible passage of dissolved silica into the blood stream produces remote effects on other organs under the conditions of an occupationally acquired dust disease of the lungs. It is recognized that the upward limit of the dust found in silicotic lungs is about 3 microns in greatest dimension, but it has not so far been possible to determine what the downward limit of size of particle which may produce fibrosis under occupational conditions may be, and in what concentration particles at that downward limit must be present. It is reasonable to conclude that the whole size range of the dust retained in the lung is significant, although it is to be expected that the reaction of the smaller particles, within the limits of their potential effect, will be more rapidly attained. It must be borne in mind that the action of siliceous dust in the lung is a cumulative reaction which only becomes significant when a certain local or general concentration of dust has been reached.

The history of this 33-year period shows clearly that immense progress has been made both medically and mechanically towards a solution of the dust problem. The distractions of war slowed down research, and, more particularly, delayed practical application of some of the lessons which had been learnt. With the ending of the war the way was clear for a great tide of improvement; as the next and last period shows, it is now in full flood.

\section{Period VI.-1946 and the Immediate Future}

Dust Prevention in Great Britain.--Strict supervision and surface test of underground drills following South African practice is to be introduced into this country. Preliminary regulations have been issued but many months must pass before all the types of rock drills which are being sold are modified to the 'vented' arrangement and have been passed. A serious problem will arise as to the continued use of the many thousands of nonvented drills in operation now. A long-term conversion plan could be achieved by a regulation that replacement parts for worn rock drills should be of the vented type.

It should be noted that vented machines are now being demanded in Rhodesia, West Africa, and elsewhere.

\section{Developments}

A number of developments have been introduced in recent years in certain mining fields which are now obtaining wider recognition. They are as follows: 

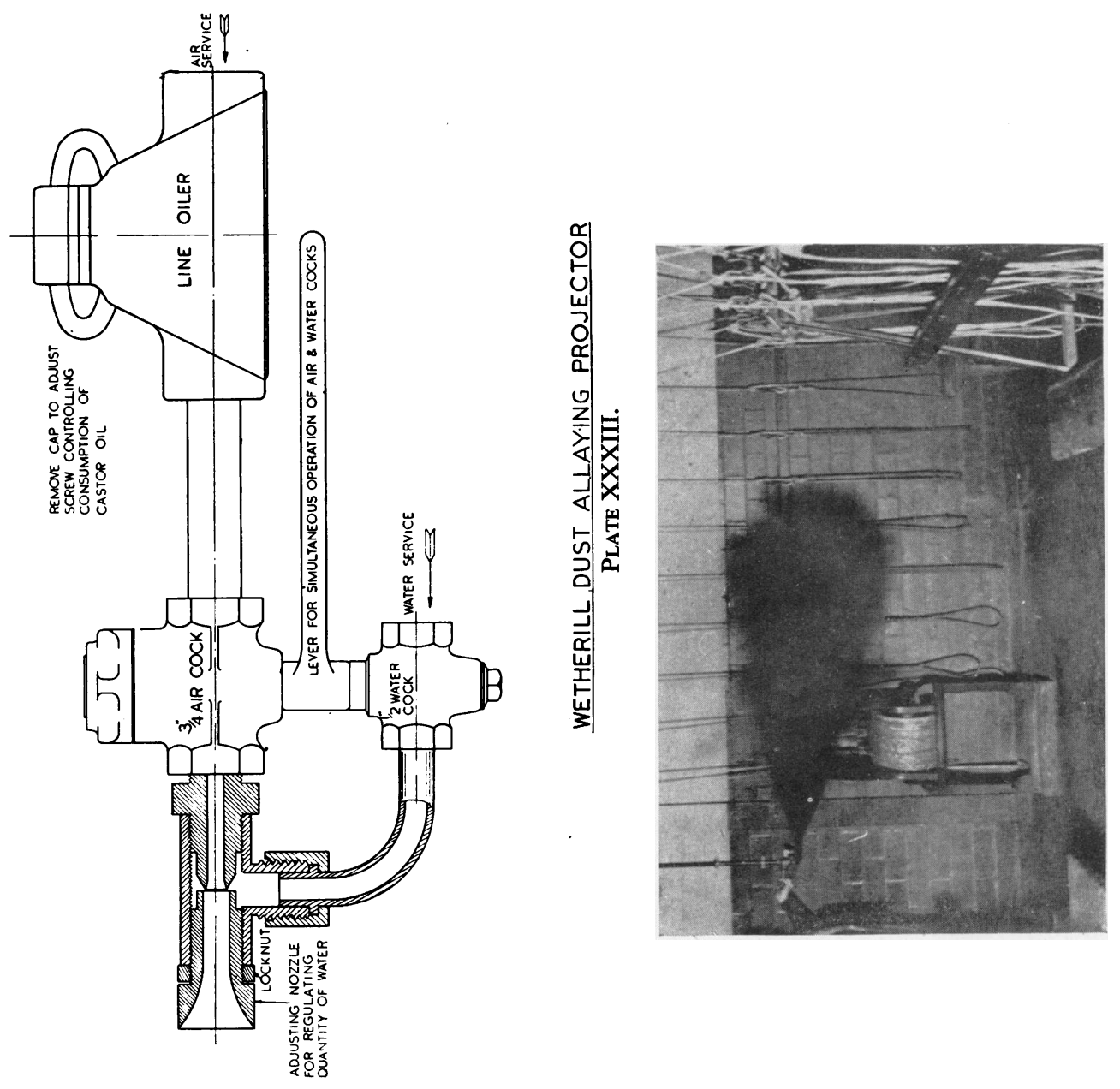
Automatic Drifters.-Rock drills of the type shown in Plate XVIII are available since the war which are entirely automatic in action. The water is turned on by the same lever and at the same instant as the compressed air, and the drill then feeds itself forward, and controls its own advance according to the hardness of the ground. When the drill has completed its run, a lever is reversed by hand and the drill retracts itself in readiness for the next drill steel. The operator is relieved from all heavy work and vibration. As the drill steel is guided by a centralizer on starting the hole, it is unnecessary for a man to be near the face whilst the machine is working. Such a drill fully vented to avoid air passing down the steel is virtually free from dust danger. Improvements in mounting these drills have been made to reduce and simplify labour.

Long Piston Hammer Drills. - In the latest form of hand-held drills a longer form of piston rod is being used which reduces the quantity of air which can escape to the vicinity of the chuck. This throws less duty on the venting ports and is an added factor of safety.

Blast-Hole Drilling.-In recent years a form of rotary drilling has been adopted in mines with large ore bodies which makes use of a light type of diamond prospecting drill. A small tube tipped with a diamond-studded crown is pressed into the rock whilst being rotated by an air operated motor. The tube extends rearwardly through the air motor part of the machine and to this end a water connexion is made. The water passes down the tube, cooling the cutting edge and allaying all dust. It is impossible for compressed air to gain access to the tube, and thus the formation of bubbles containing dry dust is prevented. This method of drilling is confined for economic reasons at present to holes of 25 feet in depth and more, owing to the relative slow rate of drilling speed. It is the safest form of drilling so far introduced for the avoidance of dust formation and it may be available later for wider use.

Foam and Wetting Agents.-The South African Report (1937) states that the results of tests with foam instead of water were entirely disappointing, but a more encouraging trial was reported in the 'Colliery Guardian,' April 12, 1946 :

'In the Kent coalfield, with the exception of one colliery, problems of dust suppression have the added urgency of a high and increasing rate of pneumonoconiosis incidence. At Chislet Colliery, where the work submitted in the present paper has been carried out, there is a good deal of hard and highly siliceous rock, containing up to 80 per cent. of free silica, which no doubt accounts for most, if not all, of the respiratory disease encountered; but a study of the percentage incidence among various grades of underground workers suggests that coal dust cannot entirely be exculpated. For that reason, although rock dust suppression has received priority, coal dust suppression has also received close attention in investigations at Chislet.

The addition of foaming agents to drilling water, with the twofold object of increasing the dust suppression efficiency of wet drilling and reducing the quantity of water required, was widely experimented with some ten years ago. It was discarded in most mining districts on account of difficulties experienced.

It was brought to the Colliery Company's notice early in 1946 that, arising from the use of foam on a tremendous scale for war-time fire fighting, an entirely new system of foam production has been devised in which water and reagent are fed to the mixing tube under constant head, with consequent elimination of the difficulties mentioned above.

Initial tests of foam drilling were made in a bed of hard sandstone rock in an old airway approximately $7 \frac{1}{2}$ by $6 \mathrm{ft}$., carrying ventilating current of less than $90 \mathrm{ft}$./ min. The ventilation conditions were thus comparable with those obtaining in a fast heading with auxiliary ventilation. Dust estimation in this and all subsequent drilling tests was by konimeter.

It was clear from the results obtained that the quantity of dust escaping to the general body of the air was negligibly small, but it was observed that, at fairly regular 15 to 20 sec. intervals, a large bubble of air escaped from the foam, and as each bubble burst a momentary haze was seen. On examination with the konimeter the haze was found to consist of a high concentration of extremely fine dust particles.

It was found that when foam was passed through the drilling equipment with the drill itself not in motion, a perfectily uniform stream was obtained, free from interruption of the kind described above, suggesting that the bubbles might be due to compressed air leaking past the piston, penetrating through the chuck and into the flush head.

In order to test this conclusion a new 'silver bullet' machine was taken into use. A vented front cover was fitted in order to prevent leakage through the cylinder building up pressure inside the chuck (Plate XXVI). This assembly was completely successful. Consistency of foam remained unaltered with the machine out of or in operation, and dust-containing bubbles were not formed.

During a full-scale practical trial in a cross-measure drift, $5107-\mathrm{ft}$. holes were put in with foam without experiencing any trouble from the foam unit or accessories.'

Tungsten Carbide Bits. - A hard metal edge is now available for tipping drill steels. The edge remains sharp for at least fifty times longer than with ordinary steel, and thus the rock is chipped rather than crushed. The percentage of the finest and most dangerous dust is less. It is claimed by some investigators that the percentage of dust under five microns in diameter is reduced. Confirmation of this point has still to be made by prolonged trials under exact control conditions. The development is worthy of study from this angle. Parallel holes can be drilled with long steels, so reducing the time 
factor and the size and weight of drill needed and thus the labour involved. The development will have, in the near future, a very far-reaching effect on all rock-drilling operations. In Plate XXXII a chisel-type bit and a cross bit are shown. The tungsten carbide tip is brazed into a steel body, which in turn is secured to a drill rod of the required length by a tapered insert.

Dust Eductor.-Yet another new development which has distinct possibilities is still in the experimental stage. This is the extraction of the dust created during drilling, through the hollow steel normally used for passing water to the cutting edge.

The eductor system was developed for the Royal Engineers before the war to remove spoil from saps in trench warfare in a silent manner. In the final development small stones, gravel, earth, and sand were educted over 1,000 feet in length to varying heights, and the system was officially adopted. In the present application the coarse dust can be removed by a cyclonic separator and the finest and most dangerous dust transmitted to a safe place for disposal. Under this system no water is required near the working face and thus working conditions can be dry and free from damp.

Wetherill Dust-Allaying Projector.-In 1935 Major A. Hibbert, D.S.O., M.C., and Mr. Charles Wetherill of the Millom and Askam Hematite Iron Co. Ltd., began experiments to allay the dust created by blasting by means of a fog projected into the face being blasted. Water by itself was first tried, but it was found to be useless as it saturated the air and held the dust particles floating, which only settled as the water evaporated. Something clearly was required to brake down the surface tension of the water. After trying various agents, castor-oil was found to answer the purpose most effectively. The form of spray as now developed is shown in Plate XXXIII. Air is supplied to the castor-oil filled line oiler at the ordinary rock drill mains' pressure of $80 \mathrm{lb}$. per sq. in. It is recommended that the water pressure should be about the same and is normally connected to the mine water service. Adjustments can be made to suit varying pressures. The method of using the spray is to set it up about 30 feet from the face to be blasted; the spray having previously been set to give the necessary fine fog, and the adjustments locked. In cases where electric detonation is used the spray is allowed to operate for three or four minutes before the charge is fired, but where fuse is used they are lit and the miners turn on the spray in passing same on their way out.

One outfit is sufficient for a drive of about $7 \mathrm{ft}$. by $7 \mathrm{ft}$. After being in operation for 10 minutes the air is usually free of dust and fumes, and miners can resume operations.

To take a specific case, Florence Mines use these sprays regularly and men restart work at the end of 10 minutes after a blast; without sprays, as much as 40 minutes is taken before men can return, and even then the end is not in comfortable working conditions.

Aluminium Prophylaxis.-It has been observed that certain substances reduce the solubility of silica. Of these substances finely powdered aluminium has proved to be one of the most effective, and Gardner and others (1944) has shown that it is an effective prophylactic in animals. The treatment is now in widespread use in Canada where it originated, in the United States, Australia, and elsewhere. It will

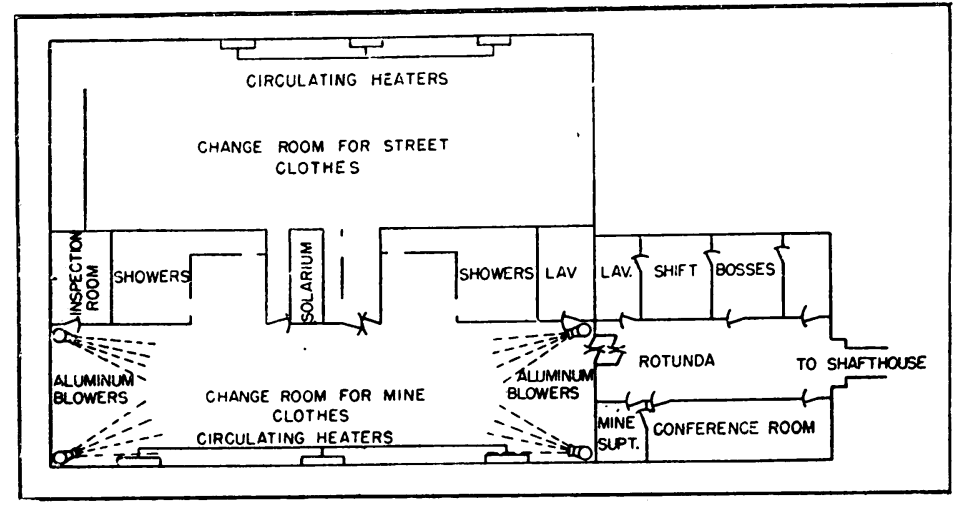

Plate XXXVI.-Diagram of floor of McIntyre change-house showing the arrangements made for aluminium prophylaxis. 
be many years before its value in human silicosis can be assessed ; and it is probable that the engineering developments discussed in this paper are likely to play a much greater part in the suppression of that disease. Nevertheless it is worth recording the technical method of applying this treatment that has been adopted, a full account of which has been given by Jacob (1946). The powder is dispersed into the change room when the men are getting ready to go underground, the room being as airtight as possible. The opening and closing of doors and entry of draughts are avoided, as the suspension of the powder is thereby dissipated. The powder used is 99 per cent. metallic aluminium. For dispersal an ejector operated (Plate XXXIV) by clean, dry, compressed air is used with an air pressure in the pipe line of $100 \mathrm{lb}$. per sq. inch, the air being turned on quickly and left full on for one minute. A quickopening tap is used, only one ejector being turned on at one time to avoid loss of particles by impingement (Plate XXXV). The dispersal is completed before the men enter the room, since there is danger from a blast of powder in the eyes. The amount of powder used is $1 \mathrm{~g}$. for each $1,000 \mathrm{cu}$. $\mathrm{ft}$. of room content based on a ten-minute exposure. If the exposure is twenty minutes the quantity is halved. After the last man has left, the room is cleared by ventilation to avoid the powder blackening the walls. The layout of the McIntyre changehouse is shown in Plate XXXVI.

\section{Recommendations}

1. The elimination of all dry drilling where dust is permitted to enter the atmosphere.

2. The venting of all drills to prevent air passing down the steel.
3. The elimination of all separate water taps and cocks near the drills so that water must pass down the hollow steel immediately the drill begins work by single lever control.

4. A highly efficient system of ventilation.

5. The lining of all underground passage-ways by cement sprayed from the cement gun.

6. Bright illumination of all working places and passage-ways by electricity.

7. Compulsory use of gloves by all underground workers.

8. Periodic medical examination of all men working underground.

\section{Bibliography}

The following books and documents have been consulted in compiling this review, and acknowledgment is made for the information so extracted. I am indebted to the Ingersoll-Rand Company tion so extracted. I am indebted to the Ingersoll-Rand Company
for the information and photograph concerning Mr. George Leyner.

Burrow, J. C. (1893). 'Mongst Mines and Miners. Simpkin, Marshall and Co. Ltd. London. (Plates 2, 3, 8, 9, 19, and 38.)

Catalogues-Ingersoll-Rand Co., Broadway, New York, U.S.A.

Catalogues-Holman Bros. Ltd., Camborne, England.

Compressed Air Magazine: J. George Leyner, Drillmaster. Broadway, New York, U.S.A. November 1938.

Darlington, John. On Rock Boring Machinery. Mining Institute of Cornwall, 1879 Gardner, L. U., Dureski, M., Delahout A. B. (1944) .J. Industr. Hyg.,

Handbook. Mines and Works Act of the Union. Hortors Ltd., Johannesburg, amended to August 1945.

Hoover, Herbert Clarke, translation of Georgius Agricola's De Re Metallica. The Mining Magazine. Salisbury House, London. 1912.

Jacob, A. W. 'Knowhow' on Fighting Silicosis with Aluminium. Engineering and Mining Journal, March 1946.

Jenkin, A. K. Hamilton. The Cornish Miner. George Allen and Unwin Ltd. London, 1927.

Lewis, George Randell (1908). The Stannaries. Houghton, Mifflin and Co., New York.

Price, F. H. Dust Suppression (Pneumonoconiosis). Colliery Guardian, Holborn, London, April 12, 1946.

Report: The Prevention of Silicosis on the Mines of the Witwatersrand. Miners' Diseases Prevention Committee. Johannesburg, June 1937.

Rosen, George (1943). The History of Miners' Diseases, a Medical and Social Interpretation. Schumens. New York.

Truscott, Professor S. J. Problems of Mining at Great Depth. Royal Cornwall Polytechnic Society, 1933. 